Review

\title{
What Is New in Biomarker Testing at Diagnosis of Advanced Non-Squamous Non-Small Cell Lung Carcinoma? Implications for Cytology and Liquid Biopsy
}

\author{
Paul Hofman 1,2
}

check for updates

Citation: Hofman, P. What Is New in Biomarker Testing at Diagnosis of Advanced Non-Squamous Non-Small Cell Lung Carcinoma? Implications for Cytology and Liquid Biopsy. J. Mol. Pathol. 2021, 2, 147-172. https:// doi.org/10.3390/jmp2020015

Academic Editor: Giuseppe Banna

Received: 23 April 2021

Accepted: 28 May 2021

Published: 4 June 2021

Publisher's Note: MDPI stays neutral with regard to jurisdictional claims in published maps and institutional affiliations.

Copyright: (C) 2021 by the author. Licensee MDPI, Basel, Switzerland. This article is an open access article distributed under the terms and conditions of the Creative Commons Attribution (CC BY) license (https:// creativecommons.org/licenses/by/ $4.0 /)$.
1 Laboratory of Clinical and Experimental Pathology, Université Côte d'Azur, CHU Nice, FHU OncoAge, Pasteur Hospital, 30 Avenue de la Voie Romaine, BP69, CEDEX 01, 06001 Nice, France; hofman.p@chu-nice.fr; Tel.: +33-4-92-03-88-55 or +33-4-92-03-87-49; Fax: +33-4-92-88-50

2 Hospital-Integrated Biobank BB-0033-00025, Université Côte d'Azur, CHU Nice, FHU OncoAge, 06001 Nice, France

\begin{abstract}
The discovery and clinical validation of biomarkers predictive of the response of nonsquamous non-small-cell lung carcinomas (NS-NSCLC) to therapeutic strategies continue to provide new data. The evaluation of novel treatments is based on molecular analyses aimed at determining their efficacy. These tests are increasing in number, but the tissue specimens are smaller and smaller and/or can have few tumor cells. Indeed, in addition to tissue samples, complementary cytological and/or blood samples can also give access to these biomarkers. To date, it is recommended and necessary to look for the status of five genomic molecular biomarkers (EGFR, $A L K$, ROS1, BRAFV600, NTRK) and of a protein biomarker (PD-L1). However, the short- and more or less long-term emergence of new targeted treatments of genomic alterations on RET and MET, but also on others' genomic alteration, notably on KRAS, HER2, NRG1, SMARCA4, and NUT, have made cellular and blood samples essential for molecular testing. The aim of this review is to present the interest in using cytological and/or liquid biopsies as complementary biological material, or as an alternative to tissue specimens, for detection at diagnosis of new predictive biomarkers of NS-NSCLC.
\end{abstract}

Keywords: lung cancer; biomarkers; cytology; liquid biopsy; diagnosis

\section{Introduction}

In recent years, therapeutic strategies for advanced-stage non-squamous non-smallcell lung carcinoma (NS-NSCLC), in particular lung adenocarcinoma, have evolved in a dramatic way due to the development of targeted therapies and immunotherapies that have significantly improved the survival of these patients [1,2]. Therefore, a number of molecular therapeutics rapidly obtained marketing approval from the Food and Drug Administration (FDA) in the USA and by the European Medicines Agency (EMA) in Europe (Table 1). Other treatments are being evaluated in clinical trials and the results already indicate a strong likelihood of novel treatments for daily practice [3-7] (Table 1). As a consequence, international recommendations have been issued for evaluation of biomarkers at diagnosis of advanced-stage NS-NSCLC [8-11]. However, the progressive increase in the number of biomarkers raises of the following questions. (i) Which technique(s) should be used for detection, while considering the delay in transmission of the results that needs to be compatible with administration of first-line treatment? (ii) What is the cost for these different tests? (iii) On what type(s) of biological sample(s) should biomarker detection be made, knowing that tissue specimens are smaller and smaller in thoracic oncology [4,12,13]? 
Table 1. Current recommended, coming soon, and potential future genomic biomarkers to be looked for at baseline in non-squamous non-small-cell carcinoma.

\begin{tabular}{ccc}
\hline EMA Approved & Coming Soon & Investigational \\
\hline$E G F R$ & $R E T$ & NRG1 \\
$A L K$ & $M E T$ & $F G F R 1$ \\
ROS1 & KRAS G12C & SMARCA4 \\
$B R A F V 600$ & $H E R 2$ & NUT \\
NTRK & & Others $(M E K$, PISKCA, STK11, etc.) \\
\hline
\end{tabular}

An appropriate daily routine practice must adapt algorithms for testing to provide a robust diagnosis, irrespective of the patient and the available biological specimens [14-33]. However, the pathologist is faced with different strategies and decisions, while taking into consideration the size, the quality and quantity of the sample, and the percentage of tumor cells. In addition to providing a diagnosis, the pathologist must evaluate the need to prescribe not only immunohistochemical analyses but also molecular tests. Therefore, the clinical pathologist is always on the front line for making decisions ( $\mathrm{go} / \mathrm{no} \mathrm{go}$ ) for further analyses. The molecular tests can be performed in a targeted way, often sequential, or with next-generation sequencing (NGS) approaches [34-39]. The increasing number of genes for analysis has created methodological constraints that depend on the nature of the biological specimen [11,40]. The use of cytological (fine-needle aspiration, bronchial aspiration, bronchoalveolar lavage, etc.) and/or liquid samples (blood, pleural effusion, cerebrospinal fluid, etc.) must allow detection of all required biomarkers for targeted therapy or immunotherapy in thoracic oncology [18,40-43]. This review presents the biomarkers that have been identified in the domain of thoracic oncology that can be potentially detected using cytological materials and/or liquid biopsies taken at diagnosis of NS-NSCLC. First, we will briefly discuss the already well-known genomic alterations present on different genes (EGFR, ALK, ROS1, BRAF), which can be targeted by different drugs in routine clinical practice, before focusing on major new molecular therapeutic targets present in other genes (NTRK, RET, MET, KRAS, HER2, NRG1, SMARCA4 and NUT).

\section{Biomarkers Assessed at Diagnosis with Cytological Samples and/or Liquid Biopsies Obtained from Advanced Non-Squamous Non-Small-Cell Lung Cancer Patients}

For therapeutic care of advanced-stage NS-NSCLC at diagnosis it is recommended to evaluate the status of at least five genomic biomarkers (the "big five": epidermal growth factor receptor (EGFR), anaplastic lymphoma kinase $(A L K)$, v-ros avian UR2 sarcoma virus oncogene homolog 1 (ROS1), v-raf murine sarcoma viral oncogene homolog B1 (BRAF), and neurotrophic tyrosine kinase (NTRK)) and the expression of programmed death-ligand 1 (PD-L1). In most countries, including France, the detection of a genomic alteration in one of these genes leads to treatment with osimertinib (EGFR mutation); alectinib, brigatinib, or lorlatinib (ALK rearrangements); crizotinib (ROS1 rearrangements); the association dabrafenib/trabetinib (BRAFV600 mutation); or larotrectinib or entrectinib (NTRK rearrangements). The tests can be performed with cytological and/or liquid samples but their sensitivity, and even their specificity, are generally more variable than tests with tissue samples [44-48]. The evaluation of PD-L1 can be performed and validated with cytological samples but has not been validated in daily routine with blood samples [41,49-52]. Aside from the "big five" biomarkers, the arrival of other biomarkers for short- (genetic alterations in proto-oncogene tyrosine-protein kinase receptor Ret (RET) and MET proto-oncogene receptor tyrosine kinase $(M E T)]$, mid- (genetic alterations in v-Ki-ras2 Kirsten rat sarcoma 2 viral oncogene homolog (KRAS), human epidermal growth factor receptor 2 ( G12CHER2), and Neuregulin 1 (NRG1)), or long-term detection (genetic alterations in SWI/SNF-related, matrix-associated, actin-dependent regulator of chromatin, subfamily $A$, member 4 (SMARCA4), nuclear protein in testis (NUT), and other genes) has to involve validation on cytological and/or blood samples (Table 1). Thus, the choice of first-line targeted therapy based on the detection of these biomarkers with 
cytological and liquid biological samples is and could be a complementary approach to tissue biopsies [42,44].

2.1. EGFR, ALK, ROS1, BRAF, and NTRK: What Is New for the "Big Five" When Using Cytological and Blood Samples?

\subsubsection{EGFR}

EGFR mutations have been detailed in many reviews and publications in the past few years and will be not detailed here. These mutations are known to be more frequently detected in nonsmoker patients and in women, but this incidence varies according to the population [53,54]. Therefore, EGFR mutations are detected in $10 \%$ to $19 \%, 15 \%$ to $20 \%, 27 \%$ to $35 \%$, and $35 \%$ to more than $48 \%$, in Caucasian, African and Middle East, Hispanic, and Asian patient populations, respectively [53-57]. Despite some discrepancies of results in a few studies, most research has shown that the frequency of EGFR mutations in African Americans is not distinct from NS-NSCLC in northern and southern Caucasian patients [58-60]. Finally, the incidence found in NS-NSCLC patients of Indian ethnicity is around $23 \%$ to $30 \%[61,62]$. At baseline, driver mutations or more rarely resistant mutations can be targeted by different tyrosine kinase inhibitors (TKIs), notably the third generation of TKIs such as osimertinib [63]. These genomic alterations are detectable on cytological samples and in liquid biopsies (LB) and are certainly the first mutations that are looked for in routine clinical practice for patients in care [63]. In this regard, many targeted sequencing methods, allowing for results in a short amount of time from cytological or blood specimens, have been used in many hospitals [64-66]. More recently, NGS methods have developed from these specimens, notably for EGFR status evaluation at baseline [67]. NGS approaches are of strong interest in order to detect different genomic alterations associated in genes other than EGFR, which may explain, at least partially, some primary resistance of TKIs targeting EGFR mutations [68]. It will be certainly mandatory soon to evaluate the landscape of the different genomic alterations present in several genes and to assess other biomarkers in situ for a better prediction of therapeutic response to medications targeting EGFR mutations or to alternatively provide immunotherapy to these patients $[68,69]$. It is noteworthy that these NGS methods will be applied not only in the late stages but also in the early stages of NS-NSCLC, which would mean patients receive adjuvant TKIs according to their EGFR status [70]. In this context, cytological and blood samples will be certainly more and more used in daily practice for NGS methods.

\subsubsection{ALK}

ALK rearrangements are present in $2 \%$ to $6 \%$ of NS-NSCLC patients according to the studies and the frequency slightly varies in the different populations $[53,71]$. These genomic alterations are sensitive to different medications, notably to the new generation of TKIs (alectinib, lorlatinib, and brigatinib) [72]. Moreover, it is crucial to detect an ALK fusion if a patient needs to be treated via immunotherapy due to an association of nonefficacy and of treatment toxicity of the immune checkpoint inhibitors (ICIs) in cases of $A L K$-positive tumors [73]. ALK status at baseline can be assessed not only in tissue biopsy but also in cytological specimens and in blood samples, notably on circulating free nucleic acids $[47,67,74]$. However, different studies demonstrated that the evaluation of ALK status can be made in circulating tumor cells at baseline. $A L K$ status can be assessed in cytological samples using ALK immunocytochemistry and ALK fluorescence in situ hybridization (FISH), which can be used at the same time for ROS1 status evaluation [75-79]. At diagnosis, the detection of $A L K$ fusion in plasma is be possible, but the sensitivity of this detection in comparison with matched tissue samples is variable according to the different studies $[46,67,74]$. RNA NGS can be used from cytological samples for $A L K$ status assessment and identification of the different partners of $A L K$ fusion [75,80]. Moreover, other technologies, such as multiplex technology based on RNA hybridization, are able to detect $A L K$ in RNA purified from tissue and also from the cytological specimen, in addition to being able to look for associated genomic alterations of interest [81,82]. ALK 
translocated lung cancers are a heterogeneous group of tumors, and it is now pivotal to evaluate $A L K$-positive NS-NSCLC at baseline in the context of their genomic background in order to more clearly predict the behavior of tumors before targeted therapy [72,82]. However, the robustness of the results greatly depends on the quantity and on the quality of the RNA, which can be significantly degraded depending on the preanalytical phase (type of fixative, time of fixation, type of cytological sample, e.g, smears or cytoblocks) [75].

\subsubsection{ROS1}

ROS1 rearrangements are detectable in $1 \%$ to $2 \%$ of NS-NSCLC patients according to the studies and the populations [83]. These genomic alterations are sensitive to some targeted therapies, mainly involving crizotinib, but some resistant mechanisms can be present during the tumor progression, leading to the possibility of other targeted therapies at baseline, such as those involving entrectinib [84], being effective. ROS1 fusion can be assessed in tissue biopsy using ROS1 IHC, but positive results have to be confirmed by ROS1 FISH or by NGS $[75,78,83,85]$. More exceptionally, ROS1 ICC and ROS1 FISH can be realized in cytological specimens $[75,77]$. RNA NGS, notably through the use of gene fusion panels that combine the possibility to detect $A L K, R E T$ or NTRK, can be used from cytological materials [83]. In plasma samples, ROS1 rearrangement can be assessed using some multiplex RT-PCR method or by using NGS [80].

\subsubsection{BRAF}

$B R A F$ mutations are detectable in different proportions in NS-NSCLC patients, according to research, and these results included not only the BRAFV600 mutations (between $2 \%$ to $3 \%$ in Caucasians) but also the non-BRAFV 600 mutations (between 5\% to $8 \%$ ) [53]. The BRAFV 600 mutations can be targeted by some BRAF inhibitors and the dabrafenib trametinib association [86]. The frequency of BRAFV600 mutations seems lower in Hispanic and Asian patients than in Caucasians [53,87]. BRAFV600 mutations can be detectable in tissue biopsy and in cytological samples using RT-PCR and V600E IHC/ICC approaches or via NGS [88,89]. In plasma samples, BRAFV600 mutations can be detectable via RT-PCR or NGS $[67,90]$.

\subsubsection{NTRK, a Very Recently Recommended Biomarker, Is One of the "Big Five"}

Fusions in NTRK can be detected in different types of solid tumors, but with a variable frequency [91-93]. Thus, some fibroblastic and thyroid tumors in children and some breast and salivary gland carcinomas have a higher incidence of this genomic alteration [91,92] In contrast, the incidence of NTRK fusions in NS-NSCLC patients is very low, less than $0.01 \%$ to $1 \%$ depending on the study and population [94-97]. In general, it concerns the youngest patients without distinction of sex in Caucasians, and, often but not always, in nonsmokers [94]. Despite this low frequency in NS-NSCLC patients, it is essential today to look for fusions in NTRK knowing the efficacy of targeted therapy for this molecular alteration [98-106]. Thus, this should now be systematically investigated in patients at diagnosis of NS-NSCLC for administration of first-line treatment [11]. Entrectinib and larotrectinib have recently been authorized by the FDA and the EMA $[107,108]$. This raises the question of which technique(s) and biological sample(s) should be used for initial systematic evaluation of these very rare fusions in thoracic oncology [109]. At the moment, most of the major studies use tissue samples for NTRK status assessment [109-111]. However, detection can be possible with cytological samples and even liquid biopsies [109,112-115]. Several techniques of detection have been developed, including immunohistochemistry (IHC), molecular biology approaches (NGS and RT-PCR), and multiplex digital colorcoded barcode technology on tissue sections [11-124]. Depending on the sensitivity and specificity of these techniques and on the biological samples used, these methods can be challenging [125]. Some studies have demonstrated interest in using Trk IHC knowing the anti-Trk antibodies are pan-Trk (anti-NTRK1, 2, 3) [109,110,126-129]. The most commercially available pan-Trk clones are A7H6R (Cell Signaling Technologies) and EPR17341 
(Abcam) [109,126-129]. Anti-Trk IHC merits several comments: (i) the sensitivity and specificity of the clones vary according to the study, (ii) knowing that incidence of this fusion in lung cancer, IHC with anti-Trk antibodies may use up biological material that could be used for some alternative approaches, notably NGS, and (iii) the cost can be substantial if IHC is used systematically since the cost of the time of the technician and of pathologist must be included, too $[110,117,125,126,130]$. IHC must also evaluate the status of NTRK on cytological samples, but in daily practice this may not be adequate. The molecular techniques include fluorescence in situ hybridization, targeted or multiplex RT-PCR, DNA- or RNA-based NGS, and analyses using NanoString technology on tissue sections $[109,119,121]$. Depending on the quality and quantity of the nucleic acids extracted from the sample, false negative results can be obtained $[78,81,109,119,121]$. Depending on the case, these approaches could be performed with cytological samples, but only a few studies in this area have been performed to date and studies comparing cytological and tissue samples are strongly needed [109,112-115]. The detection of NTRK fusions can also be envisaged with a liquid biopsy, but the sensitivity of such an approach is still unknown and needs to be determined.

\subsection{Biomarkers Just Beyond the "Big Five" in 2021}

\subsubsection{RET Fusions}

Depending on the patient's ethnicity and technique of detection, fusions in RET have been identified in $1 \%$ to $2 \%$ of NSCLC Caucasian patients and up to $9 \%$ in patients from Asia [131-133]. They occur in adenocarcinomas and, exceptionally, in adenosquamous and large-cell carcinomas $[134,135]$. These cancers are often found in nonsmokers and younger patients, with a slightly higher incidence in women, and sometimes in tumors of small size, frequently at the $\mathrm{N} 2$ stage at diagnosis $[136,137]$. RET rearrangements tend to be mutually exclusive with EGFR and KRAS mutations and ALK or ROS1 rearrangements and can be associated with a low tumor mutation burden (TMB) and a low level of PD-L1 expression [138]. Since the identification of fusions in RET in lung cancer in 2012, the number of partners of these fusions has increased $[137,139]$. The most frequent partners occur in KIF5B and CCD6, which represent around $60 \%$ and $20 \%$ of cases, respectively [137]. Different therapeutic medications targeting RET fusions have been developed, and, to date, selpercatinib and pralsetinib medications are proposed while waiting for marketing approval by the FDA and EMA [140-145]. However, testing for these fusions will now become systematic at diagnosis for all patients presenting with advanced-stage NS-NSCLC, knowing that patients with RET fusions do not generally respond well to immune checkpoint inhibitors (ICIs) [146-149]. Several techniques have been and are being used for detection of RET fusions, but their sensitivities vary and so they have gradually been abandoned [132,150]. Thus, IHC is no longer recommended, and FISH is used less and less, notably for lung cancer [151]. Targeted RT-PCR approaches are no longer used and have been replaced by multiplex RT-PCR methods as well as by DNA- and RNA-based NGS or even multiplex analytical techniques on the NanoString platform [136,150-153]. The major limitation of DNA-based NGS lies in the absence of information into effective transcription of the rearranged RET gene [113]. This approach presents a problem for RET rearrangements since they have an unusual breakpoint in RET or have a fusion partner that has never been previously characterized or identified [154]. RNA NGS analyses are certainly the most recommended for RET fusion detection due to their sensitivity and specificity [154]. However, if the amount of RNA extracted from tissues or cells is low or if, due to the formalin fixative, RNA is degraded, the RNA NGS approach has it limits. Moreover, depending on the type of NGS sequencing technique, the detection of fusion partners concerns only those known and targeted by the panel (amplicon technique) or detection of all the fusion partners (hybrid capture technique). These different techniques can be certainly applied to cytological specimens obtained in thoracic oncology. Finally, it is also possible to detect RET fusions with plasma free-circulating nucleic acids, but to date 
the sensitivity of the NGS techniques with blood samples is lower than that obtained with NGS analyses of tissues [155,156].

\subsubsection{MET Mutations}

Mutations in MET on exon 14 are present in less than $2 \%$ of lung adenocarcinomas [157]. As for EGFR, nonsmokers are overrepresented in MET-driven NSCLC cases [157]. However, a greater percentage of patients with either a MET amplification or alteration in exon 14 are smokers compared with the majority of other driver alterations [157]. MET gene aberration via exon 14 skipping has become an important therapeutic target of lung adenocarcinomas and other histological subtypes such as lung sarcomatoid carcinomas [158-160]. In the short-term, a number of medications (tepotinib and capmatinib) will certainly be used as first-line therapy as soon the FDA and EMA give marketing approval [158,159]. Thus, mutations in MET on exon 14 will soon be systematically examined at diagnosis of advanced-stage NS-NSCLC. There is a need to identify the oncogenic role of each type of MET alteration and to standardize the diagnostic approach [161]. MET exon 14 alterations have been shown to act as oncogenes and to be potentially actionable regardless of gene amplification. Indeed, MET amplification alone appears to correlate less strongly with the response to $M E T$ blockade, whereas only high amplification, excluding polysomy, appears to potentially drive the malignant phenotype and to be predictive of meaningful clinical benefit of targeted treatment. The molecular detection of MET on exon 14 skipping most often is achieved with DNA- or RNA-based NGS. However, DNA sequencing can only detect a genomic variant that alters or removes a splicing site. Conversely, RNA sequencing detects the fusion of exon 13 to 15 because this is the convergent result of any altered splicing mechanism or deletion. In addition to pre-analytical considerations, such as the degradation of RNA, the sensitivities of amplicon-mediated DNA-based approaches and hybrid capture RNA-based assays appear to differ [109,119]. Moreover, the probe in amplicon-mediated DNA-based approaches may not cover a sufficient region of interest [119]. Mutations in MET can be detected with cytological samples in lung cancer patients but also with liquid biopsies [155]. Currently, comparative studies from tissue and cytological samples or from tissue and blood samples are missing.

\subsection{Biomarkers in the Starting Block That Should Come Soon \\ 2.3.1. KRAS G12C Mutations}

Mutations in KRAS are the most frequent mutations in NS-NSCLCs, in particular for lung adenocarcinomas [162]. The incidence of these mutations varies with ethnicity as they are found in $25 \%$ to $35 \%$ of Caucasian, $10 \%$ to $13 \%$ of Asian, and $10 \%$ to $18 \%$ of Hispanic patients [55,56,87,95,162-167]. Globally, the frequency of KRAS mutations in African American patients is not distinct from Caucasians [58,59]. Mutations in KRAS are often associated with other mutations, mostly mutations in P53 [122]. The association of mutations in KRAS and serine threonine kinase 11STK11) confers poor prognosis [164]. Several factors have been found to be often associated with these mutations, including male sex, advanced age, and a specific histological subtype of adenocarcinoma, but none have yet been confirmed to date [164]. A number of subtypes of KRAS mutations exists (in particulier KRASG12C, $K R A S G 12 D$, and KRASG12V), but the most frequent is KRASG12C [162]. The reported impact of the mutation in KRAS on prognosis varies according to the studies $[164,166,168]$. Indeed, the worst prognosis seems to be associated with the presence of this mutation, nonetheless this has been questioned in some studies [168]. A lower TMB is associated with a KRASG12D mutation than with other subtypes of mutations [169].

For a long time, no targeted molecular therapy was available for KRAS mutations, but recently a personalized treatment has been made available [170]. To date, the main target is the KRASG12C mutation. Different therapeutic medications, notably sotorasib and adagrasib, are being evaluated and may be swiftly proposed to patients with tumors presenting this mutation, considering the recent excitement of many investigators in this domain [171-195]. This may soon be mandatory in the detection of the different 
subtypes of KRAS mutations in routine clinical practice. In this context, it has been recently demonstrated that the prognosis of patients having surgery for early-stage NSNSCLC showing a KRAS G12C mutation had more recurrence than in cases of other KRAS mutation subtypes or KRAS wild-type tumors, thus opening the door in the future for potential adjuvant therapy targeting KRAS G12C [196]. These assessments can be done with tissue biopsies but also with cytological samples obtained, for example, via fine-needle or bronchial aspiration [31]. These mutations can also be detected with cell-free DNA from plasma [197]. Detection can be performed with targeted RT-PCR or NGS [197]. The somatic mutations in KRAS must be distinguished from constitutional mutations in KRAS that are associated with clonal hematopoiesis, since the latter can also be detected with analyses performed with liquid biopsies considering the frequent high amount of circulating germline DNA [198-201]. It is also important to exclude the presence of other cancers associated with a KRAS mutation (in particular colon or pancreatic adenocarcinomas), which can release mutated somatic DNA into the blood [198-201].

Mutations in KRAS are often associated with an increase in the expression of PD-L1 on tumor cells and with a good response to treatment with anti-PD1/anti-PD-L1 medication [202-204]. Therefore, in the case of first-line treatment, a therapeutic strategy targeting KRASG12C can be restricted to patients with tumors expressing PD-L1 on less than $50 \%$ of tumor cells. The association of inhibitors targeting the KRASG12C mutation with ICIs may also be evaluated [205]. Other therapeutic molecules are being studied, such as inhibitors of mTOR, IGF1R, fatty acid synthase (FASN), or molecules targeting the metabolism of glutamine [206-208]. KRAS mutations can also be associated with mutations known to induce resistance to immunotherapy, such as mutations in STK11 and/or Kelch-like ECH-associated protein 1(KEAP1), which should be examined simultaneously using NGS [209-219]. Thus, in the presence of these co-mutations, specific inhibitors targeting KRASG12C could be considered and given instead of immunotherapy with anti-PD1/PD-L1 medication. However, interestingly, some studies have shown that mutations in STK11 are less frequent in KRAS mutated tumors than in wild-type KRAS tumors [220]. It should be noted that, despite the association of these mutations, a rare number of tumors are still sensitive to ICIs [221,222]. Finally, primary or acquired mechanisms of resistance to KRASG12C inhibitors have been described and should certainly be researched systematically in the future using NGS approaches [223-227].

Therefore, evaluation at diagnosis of the different mutations in KRAS and more specifically the KRASG12C mutation with cytological samples and/or liquid biopsies will soon become mandatory. The cytological samples should be used to examine, in parallel, different alterations in other genomic targets (particularly in EGFR, ALK, ROS1, BRAF, NTRK, RET, and MET) but also to evaluate the expression of PD-L1 on tumor cells [41]. Searching for mutations in STK11 and KEAP1 will also appears to be more and more useful since they are often synonymous with resistance to immunotherapy.

\subsubsection{HER2 Mutations}

HER2 overexpression is found in patients with different solid tumors, including NSCLC [228]. In NS-NSCLC, the mutational frequency in HER2 occurs in $0.9 \%$ to more than $2 \%$ of Caucasian patients, but is higher, up to $5 \%$, in Asian patients $[97,229,230]$. The presence of HER2 mutations is defined by a molecular subset of NSCLC with specific clinical-pathological features. These tumors occur in a higher frequency in Asian populations, women, nonsmokers, and in an adenocarcinoma histology even with bronchioalveolar features, a high morphological grade, TTF-1 positive staining, and a peculiar clinical presentation (disseminated lung nodules and tumor excavation), but they seem to have a similar survival compared with other molecularly defined cohorts [231,232]. Despite the higher prevalence in these specific subgroups of patients, HER2 mutations may be found too in men and heavy smokers. Finally, it seems that a high incidence of brain metastases is detected at diagnosis and on tumor progression in patients having a HER2 mutation [233]. 
Several therapeutic medications targeting HER2 mutations have been developed for lung cancer [234-242]. Notably, it was recently reported that trastuzumab deruxtecan achieved a clinically significant tumor response in patients with HER2-mutant-advanced NS-NSCLC whose disease had progressed following one or more previous systemic therapies (chemotherapy or immunotherapy with immune checkpoint inhibitors against PD1/PD-L1) $[237,240]$ Thus, the search for these mutations either with tissue or cytological samples, or liquid biopsies, may soon become indispensable, too, at diagnosis of advancedstage NS-NSCLC. Several approaches can be used to evaluate the status of HER2 [243,244]. It seems that using HER2 IHC or HER2 FISH will be not adequate methods in tissue and cytological sample tests, notably due the low frequency of HER2 mutations in NS-NSCLC. Given the increasing number of genes for analysis and for precision medicine in these patients, the most appropriate method to assess HER2 status from cytological material and/or liquid biopsies will be certainly DNA- or RNA-based NGS.

\subsection{What about Other Biomarkers of Interest?}

\subsubsection{NRG1 Fusions}

Fusions in NRG1 have been identified and could soon become molecular therapeutic targets [245]. These fusions are present on a certain number of solid lung cancers [246,247]. According to the literature, the incidence is estimated to be low, between $0.1 \%$ and $0.4 \%$ of NS-NSCLC patients [246,247]. A number of partner fusions exist, where CD74-NRG1 has emerged as the most frequently reported in NRG1 rearranged lung tumors [248]. It is interesting to note that fusions in NRG1 are present in more than $5 \%$ of a histological subtype of lung adenocarcinomas, invasive mucinous lung adenocarcinomas [249]. Clinical trials targeting fusions in NRG1 are presently being evaluated [249]. Indeed, existing ErbBtargeted treatments have potential as targeted therapies for patients with tumors harboring NRG1 fusions [245].

The detection of these fusions is presently performed with NGS approaches and essentially using RNA sequencing $[133,249]$. Detection can be performed with tissue biopsies, but certainly with cytological specimens and cell-free tumor nucleic acids in plasma [246]. However, currently, no studies have compared the sensitivity and specificity of the methods for NRG1 fusion detection with different types of biological material.

\subsubsection{SMARCA4 Mutations}

A relatively new type of thoracic cancer, in particular lung cancer, with a poor prognosis has been identified to have mutations in SMARCA4 [250-258]. These mutations have been found in about $5 \%$ to $10 \%$ of NSCLC patients, mostly NS-NSCLC patients [259]. These mutations are mutually exclusive, with genomic alterations in ALK, ROS1, MET, and RET [260]. However, co-mutations in KEAP1, STK11, and KRAS are more frequent in SMARCA4-mutated tumors [261]. A few therapeutic medications targeting these mutations are under development, mostly tested in vitro but some are being evaluated in clinical trials, too [259,262-266]. ICIs have been found to be efficacious in patients with SMARCA4-mutated tumors [267-269]. However, cases of hyper progression of tumors after administration of ICIs have been reported, too [270].

Mutations in SMARCA4 constitute a family of mutations present in the SWI/SNF complex, in which other mutations exist, including mutations in SMARCA2 [271]. Morphological and phenotypical characteristics can point sometimes to such mutations, since these cancers can contain rhabdoid cells or even poorly differentiated cells associated with islets of epidermoid cells $[250,251]$. One of the key diagnostic elements is the absence of expression in the majority of cases of TTF1 on tumor cells [250,251]. Thus, all the lung adenocarcinomas that do not express TTF1 must be examined for mutations in SMARCA4. In this context, IHC with anti-BRG1 antibodies that show the loss of expression of BRG1 in the nuclei of tumor cells but expression in the nuclei of lymphocytes confirms the diagnosis [272-275] (Figure 1). Indeed, when a cytological sample from a patient with lung cancer is negative for TTF1 and BRG1, a mutation in SMARCA4 must be sought and confirmed 
using molecular biology approaches, mainly NGS [275] (Figure 1). These mutations can be detected with NGS not only on tissue biopsies but certainly on cytological samples and liquid biopsies, too [259].
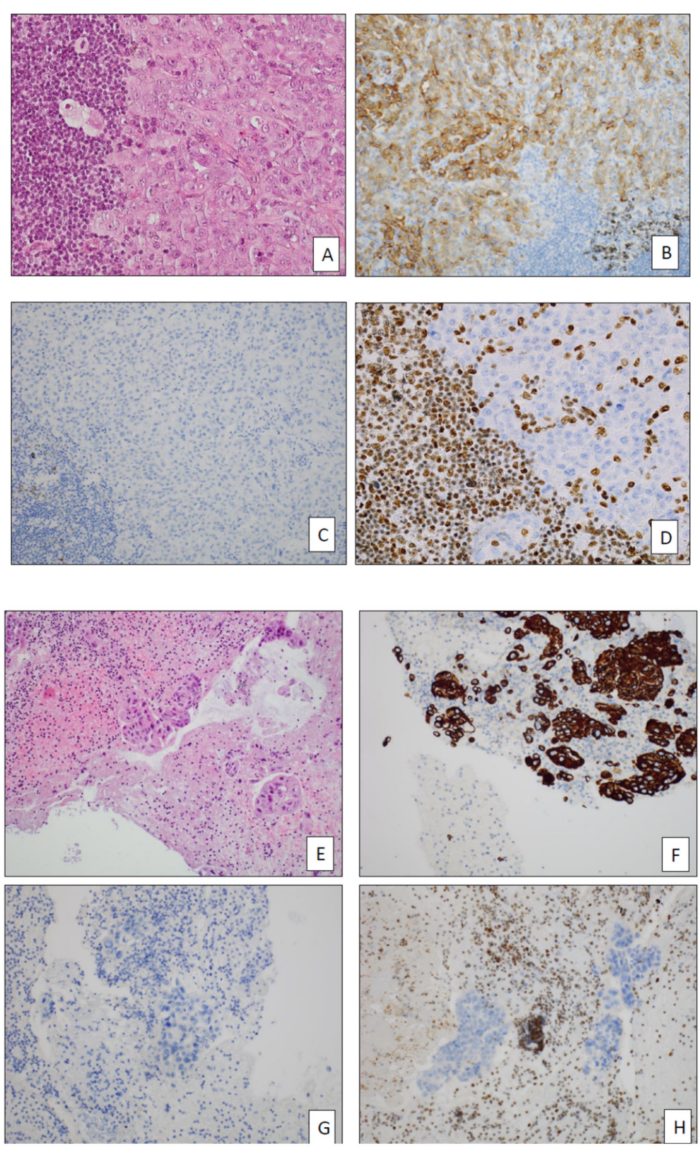

Figure 1. SMARCA4-mutated lung carcinoma. Tissue (A-D) and cytological (E-H) samples from the same patient. (A-D) Transthoracic core biopsy. (A) Proliferation of a poorly differentiated carcinoma (hematoxylin eosin, magnification $\times 200$ ). (B) Expression of cytokeratins (anti-pancytokeratins antibody, immunoperoxidase, magnification $\times 200$ ). (C) Absence of TTF1 expression on tumor cells (anti-TTF1 antibody, immunoperoxidase, magnification $\times 200$ ). (D) Tumor showing an absence of BRG1 expression on tumor cells but with a strong expression of BRG1 on lymphocytes (antiBRG1, ab4081 clone, immunoperoxidase, magnification $\times 200)$. (E-H) Endobronchial ultrasound (EBUS)-guided transbronchial needle aspiration. (E) Different size of tumor cell nests without differentiation (hematoxylin eosin, magnification $\times 200$ ). (F) Strong expression of cytokeratins (anticytokeratin 7 antibody, immunoperoxidase, magnification $\times$ 200). (G) Absence of TTF1 nuclear staining in tumor cells (anti-TTF1 antibody, immunoperoxidase, magnification $\times 200$ ). (H) Absence of BRG1 staining in nuclei tumor cells associated with BRG1 expression in lymphocytes (ab4081 clone, immunoperoxidase, magnification $\times 200$ ).

\subsubsection{NUT (Nuclear Protein in Testis) Rearrangements}

Nuclear protein in testis (NUT) carcinomas are very rare, notably among lung cancers, but are very aggressive tumors [276-282]. These tumors are more frequent in pediatric populations, in particular tumors that develop on the median anatomical axis above the diaphragm $[253,283,284]$. Histological examination shows poorly differentiated carcinoma cells with a mesenchymal-to-epithelial transition phenotype [285] (Figure 2). Rare cases of squamous cell carcinomas showing rearrangement in NUT have been reported [286]. These tumors have chromosome rearrangements in the NUT gene on chromosome 15 [287]. In 70\% to $78 \% \%$ of cases, a translocation $\mathrm{t}(15 ; 19)$ subsequent to fusion of NUT with bromodomaincontaining protein 4 (BRD4) on chromosome 19 occurs $[287,288]$. Other rarer partners, 
including BRD3 (15\%) and NSD3-NUTM1 (6\%), have been described [287,288]. While very rarely diagnosed, the number of NUT lung cancers may be underestimated [286,289-291]. Thus, diagnosis can be made with IHC using anti-NUT antibodies that stain the nucleus of tumor cells [292-294] (Figure 2). The result can be confirmed with a FISH analysis using probes against NUT or even better with NGS to also identify a fusion partner [295-297]. Diagnosis of NUT carcinoma can be performed with cytological material [298] (Figure 2). In this situation, the sample often contains many poorly cohesive tumor cells or, conversely, more cohesive tumor cells with small- or intermediate-sized nuclei with a single nucleolus within fine or fragmented granular chromatin [298,299] (Figure 2). The size of the nucleus is about twice that of the nucleus of a lymphocyte [298]. The cytological images are often rather similar to those described for small-cell lung carcinomas or poorly differentiated carcinomas $[298,299]$. Another differential diagnosis must be considered for an exceptional primitive lung Ewing sarcoma, too [298]. NUT carcinomas express cytokeratins (Figure 2) and P63 but are often negative for neuroendocrine markers and TTF1 [300]. However, some rare tumors can nonetheless be positive for TTF1, chromogranin (Figure 2), synaptophysin, or P40 or be negative for P63 [300-303]. Finally, NUT carcinoma can be identified with cytological samples using anti-NUT antibodies and confirmed by NGS [298,304] (Figure 2). Even if to the best of our knowledge no NUT lung carcinoma has been currently diagnosed using a liquid biopsy, this may be feasible in theory using NGS approaches.
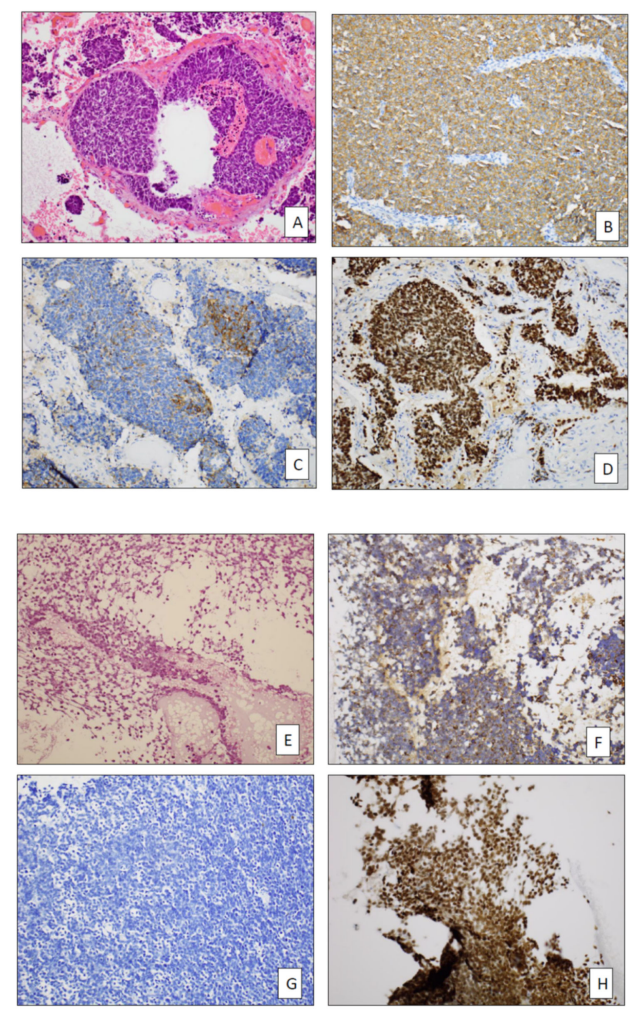

Figure 2. NUT lung carcinoma. Tissue (A-D) and cytological (E-H) samples from the same patient. (A-D) Tissue specimen from a lobectomy. (A) Proliferation of a poorly differentiated carcinoma (hematoxylin eosin, magnification $\times 200$ ). (B) Expression of cytokeratins (anti-pancytokeratins antibody, immunoperoxidase, magnification $\times 200$ ). (C) A rare NUT tumor expressing the chromogranin (anti-chromogranin antibody, immunoperoxidase, magnification $\times 200$ ). (D) Expression of the protein NUT in the nuclei of carcinoma cells (anti-NUT, clone C52B1, immunoperoxidase, magnification $\times$ 200). (E-H) Bronchial aspirates. (E) Numerous poorly differentiated and small and non-cohesive tumor cells (hematoxylin eosin, magnification $\times 200$ ). (F) Weak staining with anti-pancytokeratin antibody (immunoperoxidase, magnification $\times 200$ ). (G) Absence of TTF1 expression in tumor cells (anti-TTF1 antibody, immunoperoxidase, magnification $\times 200$ ). (H) Strong expression of the protein NUT in tumor cell nuclei (anti-NUT, clone C52B1, immunoperoxidase, magnification $\times 200$ ). 
Several clinical trials are ongoing with molecules targeting the bromodomain and extra terminal domain (BET) proteins, which underlines the possible future need to identify these NUT carcinomas for personalized treatment, even if these tumors can also be sensitive to ICIs for a long period [287,305-308]. Notably, the current knowledge of BRD4-NUT function has been leveraged for the therapeutic development of first-in-class BET inhibitors, but also other targeted strategies [309-311].

\subsubsection{Others Potential Biomarkers of Interest}

Other biomarkers are being studied and may join the list of genomic alterations for detection in different genes (such as STK11, KEAP1, mitogen-activated protein kinase (MEK), and phosphatidylinositol 3-kinase catalytic $\alpha$ (PI3KCA)) at diagnosis of advanced-stage NSNSCLC (Table 1). In particular, some biomarkers may be useful in predicting positive (a high TMB) or negative responses (mutations in STK11 and KEAP1) to treatment with ICIs [312,313]. Certain mutations, such as those in STK11, can also open up new avenues of targeted therapies and may be detected with IHC [314,315]. It is noteworthy that the frequency of STK11 mutations in NS-NSCLC patients seems to be lower (4\% in Asians) or higher (25\% in African Americans) according to the populations, and comparative to the incidence observed in Caucasians (around 14\%) [53,316,317]. To detect genomic alterations in fibroblast growth factor receptor (FGFR), biomarkers have been developed but their therapeutic application is still preliminary and concerns mostly squamous cell carcinomas of the lung [318-322].

\section{What Are the Consequences for Cytology and Liquid Biopsy Practices?}

Liquid biopsies and cytological examinations at diagnosis are being used more and more often in daily practice in thoracic oncology. Today, to search for an increasing number of biomarkers predictive of the response to targeted therapies or immunotherapies, the analyses need biological samples from different sources [323,324]. Genomic alteration assessment is feasible on many cytological samples having different preparations [325-327]. Therefore, it is pivotal to perfectly integrate these approaches since in a large number of NSCLC patients the cytology specimen may be the only source of sample available for diagnosis. Mastering and knowing the potential and the limitations of different cytological preparations is mandatory to manage and optimize them for ancillary studies, notably molecular testing, that guide precision medicine. Aside from the use of cytological materials, liquid biopsies can detect a molecular target when a tissue biopsy or a cytological sample cannot be obtained from an inaccessible tumor or in the case of an insufficient number of carcinoma cells [328-330]. However, liquid biopsies at baseline have their limits, in particular in the case of a low amount of circulating DNA from small-sized tumors or in the case of certain metastatic sites (like the brain) that release very little DNA material into the blood $[67,331]$. Thus, the sensitivity of the different tests for detection of genomic alterations, in particular fusions and amplifications, is globally lower than tests performed with tissue or cells [155]. Moreover, DNA from tissue or circulating in blood can give discordant results [155]. One of the advantages of liquid biopsies compared to tissue biopsies and cytological samples is the possibility of evaluating the tumor heterogeneity, and, thus, of detecting genomic alterations that are sometimes absent from certain tumor sites [332]. Another advantage is certainly the delay in obtaining a result from liquid biopsies, which is shorter compared to tissue biopsies, allowing for adherence to certain international recommendations that require the results be obtained within less than 10 days. Thus, in real life studies, systematic performance of NGS analyses with liquid biopsies show a number of advantages compared to analyses performed with tissue biopsies [333].

While difficult to perform in the routine practice, TMB is a predictive factor in the evaluation of the response to ICIs [334]. Some studies have shown that the analysis of TMB at diagnosis with circulating DNA and with cytological samples can predict the response to ICIs [335-338]. However, analysis of the TMB is not yet performed in most countries and holds a number of limits for use in clinical routine practices [339]. In this regard, 
it is essential to perform validation studies evaluating the sensitivity and specificity of the different molecular tests performed with blood and/or cytology compared to tissue specimens before using TMB results obtained with the biological specimens in daily routine.

Altogether, it is of interest to develop an integrative approach that can associate analyses performed with tissues, cytological samples, and those with liquid samples, in particular blood [14,340,341] (Figure 3). Even if NGS approaches from liquid biopsies gain momentum in daily practice they still need to be associated with NGS approaches from nucleic acids extracted from tissue and/or cytological samples. While most of the clinical studies into liquid biopsies are performed with free circulating nucleic acids, a few studies have demonstrated the interest in combining several circulating components for optimal analysis of certain biomarkers [342,343].

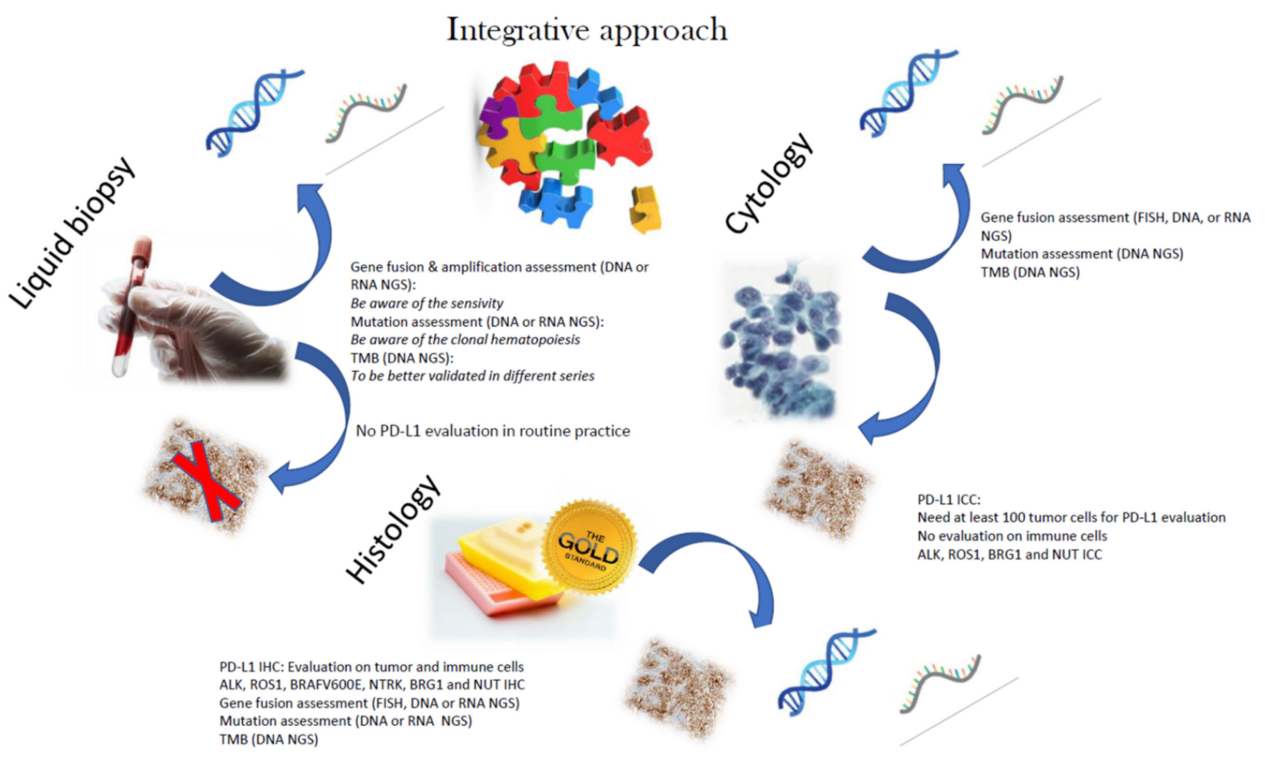

Figure 3. The complementary role of tissue biopsies, cytological specimens, and liquid biopsies for the characterization of presently available and future biomarkers at diagnosis of non-squamous non-small cell lung carcinomas.

\section{Conclusions}

Improvement in our understanding of the pathophysiological mechanisms of NSCLC and the successive discovery of different predictive biomarkers have significantly modified and made complex both therapeutic and molecular testing algorithms in thoracic oncology. In fact, aside from obtaining the status of EGFR, ALK, ROS1, BRAF, and NTRK before proceeding with immunotherapy (reserved for patients with more than $50 \%$ of tumor cells expressing PD-L1) or immunotherapy associated with chemotherapy (irrespective of the expression of PD-L1 on tumor cells), it is going to be necessary in the short-term to look for genomic alterations in other genes (RET, MET, HER2, KRAS, NRG1, etc.) at diagnosis. Treating patients with first-line immunotherapy or immunotherapy combined with chemotherapy can be deleterious when patients present with activated mutations in EGFR and, depending on the case, rearrangements in $A L K$ and ROS1 [344,345]. For the other genes, the results to date are contradictory and the small number of comparative trials performed at baseline do not allow a consensus to be drawn. However, clinicians need to strongly consider the benefits and risks of starting immunotherapy in symptomatic patients without knowing the complete genomic profile of the tumor, as prescribing suboptimal therapy based on perceived medical urgency may jeopardize outcomes and lead to useless and dangerous toxicity. The choice of the biological specimens of interest for detection of molecular genomic and/or protein biomarkers has evolved, and should integrate tissue biopsies, cytological samples, and/or liquid biopsies to better take care of patients with NS-NSCLC. 
Funding: This research received no external funding.

Institutional Review Board Statement: Not applicable.

Informed Consent Statement: Not applicable.

Data Availability Statement: Not applicable.

Acknowledgments: The author thanks Christiane Brahimi-Horn for editing this manuscript, the Conseil Départemental des Alpes Maritimes, the Institut National du Cancer (INCa), the Ligue Départementale de Lutte contre le Cancer des Alpes Maritimes, and the Canceropôle PACA.

Conflicts of Interest: The author declares no conflict of interest.

\section{References}

1. Herbst, R.S.; Morgensztern, D.; Boshoff, C. The biology and management of non-small cell lung cancer. Nature 2018, 553, 446-454. [CrossRef] [PubMed]

2. Howlader, N.; Forjaz, G.; Mooradian, M.J.; Meza, R.; Kong, C.Y.; Cronin, K.A.; Mariotto, A.B.; Lowy, D.R.; Feuer, E.J. The Effect of Advances in Lung-Cancer Treatment on Population Mortality. N. Engl. J. Med. 2020, 383, 640-649. [CrossRef] [PubMed]

3. Malapelle, U.; Muscarella, L.A.; Pisapia, P.; Rossi, A. Targeting emerging molecular alterations in the treatment of non-small cell lung cancer: Current challenges and the way forward. Expert Opin. Investig. Drugs 2020, 29, 363-372. [CrossRef] [PubMed]

4. Pisapia, P.; Pepe, F.; Troncone, G.; Malapelle, U. Predictive biomarkers for molecular pathology in lung cancer. Biomark. Med. 2020, 14, 253-257. [CrossRef] [PubMed]

5. Russo, A.; Lopes, A.R.; McCusker, M.G.; Garrigues, S.G.; Ricciardi, G.R.; Arensmeyer, K.E.; Scilla, K.A.; Mehra, R.; Rolfo, C. New Targets in Lung Cancer (Excluding EGFR, ALK, ROS1). Curr. Oncol. Rep. 2020, 22, 48. [CrossRef]

6. Tsakonas, G.; Ekman, S. Oncogene-addicted non-small cell lung cancer and immunotherapy. J. Thorac. Dis. 2018, 10, 1547-1555. [CrossRef] [PubMed]

7. Yang, C.-Y.; Yang, J.C.-H.; Yang, P.-C. Precision Management of Advanced Non-Small Cell Lung Cancer. Annu. Rev. Med. 2020, 71, 117-136. [CrossRef]

8. Clinical Practice Guidelines on Lung Cancer. Available online: https://www.esmo.org/guidelines/lung-and-chest-tumours (accessed on 9 November 2020).

9. NCCN Clinical Practice Guidelines in Oncology. Available online: https://www.nccn.org/guidelines/category_1 (accessed on 10 December 2020).

10. Lindeman, N.I.; Cagle, P.T.; Aisner, D.L.; Arcila, M.E.; Beasley, M.B.; Bernicker, E.H.; Colasacco, C.; Dacic, S.; Hirsch, F.R.; Kerr, K.; et al. Updated Molecular Testing Guideline for the Selection of Lung Cancer Patients for Treatment With Targeted Tyrosine Kinase Inhibitors: Guideline From the College of American Pathologists, the International Association for the Study of Lung Cancer, and the Association for Molecular Pathology. Arch. Pathol. Lab. Med. 2018, 142, 321-346. [CrossRef]

11. Mosele, F.; Remon, J.; Mateo, J.; Westphalen, C.; Barlesi, F.; Lolkema, M.; Normanno, N.; Scarpa, A.; Robson, M.; Meric-Bernstam, F.; et al. Recommendations for the use of next-generation sequencing (NGS) for patients with metastatic cancers: A report from the ESMO Precision Medicine Working Group. Ann. Oncol. 2020, 31, 1491-1505. [CrossRef]

12. De Toma, A.; Russo, G.L.; Signorelli, D.; Pagani, F.; Randon, G.; Galli, G.; Prelaj, A.; Ferrara, R.; Proto, C.; Ganzinelli, M.; et al. Uncommon targets in non-small cell lung cancer: Everyone wants a slice of cake. Crit. Rev. Oncol. 2021, 160, 103299. [CrossRef]

13. Faber, E.; Grosu, H.; Sabir, S.; Lucas, F.A.S.; Barkoh, B.A.; Bassett, R.L.; Luthra, R.; Stewart, J.; Roy-Chowdhuri, S. Adequacy of small biopsy and cytology specimens for comprehensive genomic profiling of patients with non-small-cell lung cancer to determine eligibility for immune checkpoint inhibitor and targeted therapy. J. Clin. Pathol. 2021. [CrossRef]

14. Aisner, D.L.; Rumery, M.D.; Merrick, D.T.; Kondo, K.L.; Nijmeh, H.; Linderman, D.J.; Doebele, R.C.; Thomas, N.; Chesnut, P.C.; Varella-Garcia, M.; et al. Do More With Less: Tips and Techniques for Maximizing Small Biopsy and Cytology Specimens for Molecular and Ancillary Testing: The University of Colorado Experience. Arch. Pathol. Lab. Med. 2016, 140, 1206-1220. [CrossRef]

15. Angerilli, V.; Galuppini, F.; Pagni, F.; Fusco, N.; Malapelle, U.; Fassan, M. The Role of the Pathologist in the Next-Generation Era of Tumor Molecular Characterization. Diagnostics 2021, 11, 339. [CrossRef]

16. Bubendorf, L.; Lantuejoul, S.; De Langen, A.J.; Thunnissen, E. Nonsmall cell lung carcinoma: Diagnostic difficulties in small biopsies and cytological specimens. Eur. Respir. Rev. 2017, 26, 170007. [CrossRef]

17. Canberk, S.; Tischler, V.; Engels, M. Current Topics and Practical Considerations of Cytology Practice in Lung Cancer: Reflexions from the Lung Symposium at the 42nd European Congress of Cytology, Malmö. Acta Cytol. 2020, 64, 463-470. [CrossRef] [PubMed]

18. Canberk, S.; Engels, M. Cytology samples and molecular biomarker testing in lung cancer-Advantages and challenges. Virchows Arch. 2021, 478, 45-57. [CrossRef] [PubMed]

19. Chaddha, U.; Hogarth, D.K.; Murgu, S. The role of endobronchial ultrasound transbronchial needle aspiration for programmed death ligand 1 testing and next generation sequencing in advanced non-small cell lung cancer. Ann. Transl. Med. 2019, 7, 351. [CrossRef] 
20. Coley, S.M.; Crapanzano, J.P.; Saqi, A. FNA, core biopsy, or both for the diagnosis of lung carcinoma: Obtaining sufficient tissue for a specific diagnosis and molecular testing. Cancer Cytopathol. 2015, 123, 318-326. [CrossRef]

21. Danakas, A.M.; Jones, C.E.; Magguilli, M.; Lada, M.J.; Plavnicky, J.; Parajuli, S.; Wizorek, J.J.; Peyre, C.G.; Ettel, M.; Sweeney, M.; et al. Optimising rapid on-site evaluation-assisted endobronchial ultrasound-guided transbronchial needle aspiration of mediastinal lymph nodes: The real-time cytopathology intervention process. Cytopathology 2021, 32, 318-325. [CrossRef] [PubMed]

22. El Messaoudi, S.; Rolet, F.; Mouliere, F.; Thierry, A.R. Circulating cell free DNA: Preanalytical considerations. Clin. Chim. Acta 2013, 424, 222-230. [CrossRef]

23. Furuya, N.; Matsumoto, S.; Kakinuma, K.; Morikawa, K.; Inoue, T.; Saji, H.; Goto, K.; Mineshita, M. Suitability of transbronchial brushing cytology specimens for next-generation sequencing in peripheral lung cancer. Cancer Sci. 2021, 112, 380-387. [CrossRef]

24. Hofman, P. The challenges of evaluating predictive biomarkers using small biopsy tissue samples and liquid biopsies from non-small cell lung cancer patients. J. Thorac. Dis. 2019, 11, S57-S64. [CrossRef]

25. Ilie, M.; Hofman, P. Pros: Can tissue biopsy be replaced by liquid biopsy? Transl. Lung Cancer Res. 2016, 5, 420-423. [CrossRef]

26. Jain, D.; Allen, T.C.; Aisner, D.L.; Beasley, M.B.; Cagle, P.T.; Capelozzi, V.L.; Hariri, L.P.; Lantuejoul, S.; Miller, R.; Mino-Kenudson, M.; et al. Rapid On-Site Evaluation of Endobronchial Ultrasound-Guided Transbronchial Needle Aspirations for the Diagnosis of Lung Cancer: A Perspective From Members of the Pulmonary Pathology Society. Arch. Pathol. Lab. Med. 2017, 142, $253-262$. [CrossRef]

27. Keppens, C.; Van Royen, M.Y.; Brysse, A.; Cotteret, S.; Høgdall, E.; Kuhlmann, T.P.; O’Sullivan, B.; Pauwels, P.; Pauwels, S.; Rot, M.; et al. Incidents in Molecular Pathology: Frequency and Causes During Routine Testing. Arch. Pathol. Lab. Med. 2021. [CrossRef]

28. Leong, T.L.; Christie, M.; Kranz, S.; Pham, K.; Hsu, A.; Irving, L.B.; Asselin-Labat, M.-L.; Steinfort, D.P. Evaluating the Genomic Yield of a Single Endobronchial Ultrasound-guided Transbronchial Needle Aspiration in Lung Cancer: Meeting the Challenge of Doing More With Less. Clin. Lung Cancer 2017, 18, 467-472. [CrossRef] [PubMed]

29. Lozano, M.D.; Echeveste, J.I.; Abengozar, M.; Mejías, L.D.; Idoate-Gastearena, M.-Á.; Calvo, A.; De Andrea, C.E. Cytology Smears in the Era of Molecular Biomarkers in Non-Small Cell Lung Cancer: Doing More With Less. Arch. Pathol. Lab. Med. 2018, 142, 291-298. [CrossRef] [PubMed]

30. Pisapia, P.; Malapelle, U.; Troncone, G. Liquid Biopsy and Lung Cancer. Acta Cytol. 2019, 63, 489-496. [CrossRef] [PubMed]

31. Pisapia, P.; Malapelle, U.; Roma, G.; Saddar, S.; Zheng, Q.; Pepe, F.; Bruzzese, D.; Vigliar, E.; Bellevicine, C.; Luthra, R.; et al. Consistency and reproducibility of next-generation sequencing in cytopathology: A second worldwide ring trial study on improved cytological molecular reference specimens. Cancer Cytopathol. 2019, 127, 285-296. [CrossRef]

32. Sacher, G.A.; Komatsubara, K.M.; Oxnard, G.R. Application of Plasma Genotyping Technologies in Non-Small Cell Lung Cancer: A Practical Review. J. Thorac. Oncol. 2017, 12, 1344-1356. [CrossRef] [PubMed]

33. Salvianti, F.; Gelmini, S.; Costanza, F.; Mancini, I.; Sonnati, G.; Simi, L.; Pazzagli, M.; Pinzani, P. The pre-analytical phase of the liquid biopsy. N. Biotechnol. 2020, 55, 19-29. [CrossRef] [PubMed]

34. Roy-Chowdhuri, S.; Pisapia, P.; Salto-Tellez, M.; Savic, S.; Nacchio, M.; De Biase, D.; Tallini, G.; Troncone, G.; Schmitt, F. Invited review-next-generation sequencing: A modern tool in cytopathology. Virchows Arch. 2019, 475, 3-11. [CrossRef]

35. Seto, K.; Masago, K.; Fujita, S.; Haneda, M.; Horio, Y.; Hida, T.; Kuroda, H.; Hosoda, W.; Okubo, K. Targeted RNA sequencing with touch imprint cytology samples for non-small cell lung cancer patients. Thorac. Cancer 2020, 11, 1827-1834. [CrossRef] [PubMed]

36. Stoy, S.P.; Segal, J.P.; Mueller, J.; Furtado, L.V.; Vokes, E.E.; Patel, J.D.; Murgu, S. Feasibility of Endobronchial Ultrasound-guided Transbronchial Needle Aspiration Cytology Specimens for Next Generation Sequencing in Non-small-cell Lung Cancer. Clin. Lung Cancer 2018, 19, 230-238. [CrossRef]

37. Troncone, G.; Roy-Chowdhuri, S. Key Issues in Molecular Cytopathology. Arch. Pathol. Lab. Med. 2018, 142, 289-290. [CrossRef]

38. Xie, F.; Zheng, X.; Mao, X.; Zhao, R.; Ye, J.; Zhang, Y.; Sun, J. Next-Generation Sequencing for Genotyping of Endobronchial Ultrasound-Guided Transbronchial Needle Aspiration Samples in Lung Cancer. Ann. Thorac. Surg. 2019, 108, 219-226. [CrossRef]

39. Young, K.; Santos, G.D.C.; Card, P.; Leighl, N. The role of cytology in molecular testing and personalized medicine in lung cancer: A clinical perspective. Cancer Cytopathol. 2019, 127, 72-78. [CrossRef]

40. Bellevicine, C.; Malapelle, U.; Vigliar, E.; Pisapia, P.; Vita, G.; Troncone, G. How to prepare cytological samples for molecular testing. J. Clin. Pathol. 2017, 70, 819-826. [CrossRef] [PubMed]

41. Gosney, J.R.; Boothman, A.-M.; Ratcliffe, M.; Kerr, K.M. Cytology for PD-L1 testing: A systematic review. Lung Cancer 2020, 141, 101-106. [CrossRef]

42. Hofman, P.; Heeke, S.; Alix-Panabières, C.; Pantel, K. Liquid biopsy in the era of immuno-oncology: Is it ready for prime-time use for cancer patients? Ann. Oncol. 2019, 30, 1448-1459. [CrossRef]

43. Rolfo, C.; Cardona, A.F.; Cristofanilli, M.; Paz-Ares, L.; Diaz Mochon, J.J.; Duran, I.; Raez, L.E.; Russo, A.; Lorente, J.A.; Malapelle, U.; et al. Challenges and opportunities of cfDNA analysis implementation in clinical practice: Perspective of the International Society of Liquid Biopsy (ISLB). Crit. Rev. Oncol. Hematol. 2020, 151, 102978. [CrossRef]

44. Imyanitov, E.N.; Iyevleva, A.G.; Levchenko, E.V. Molecular testing and targeted therapy for non-small cell lung cancer: Current status and perspectives. Crit. Rev. Oncol. 2021, 157, 103194. [CrossRef] 
45. Ilié, M.; Mazières, J.; Chamorey, E.; Heeke, S.; Benzaquen, J.; Thamphya, B.; Boutros, J.; Tiotiu, A.; Fayada, J.; Cadranel, J.; et al. Prospective Multicenter Validation of the Detection of ALK Rearrangements of Circulating Tumor Cells for Noninvasive Longitudinal Management of Patients With Advanced NSCLC. J. Thorac. Oncol. 2021, 16, 807-816. [CrossRef] [PubMed]

46. Leighl, N.B.; Page, R.D.; Raymond, V.M.; Daniel, D.B.; Divers, S.G.; Reckamp, K.L.; Villalona-Calero, M.A.; Dix, D.; Odegaard, J.I.; Lanman, R.B.; et al. Clinical Utility of Comprehensive Cell-free DNA Analysis to Identify Genomic Biomarkers in Patients with Newly Diagnosed Metastatic Non-small Cell Lung Cancer. Clin. Cancer Res. 2019, 25, 4691-4700. [CrossRef] [PubMed]

47. Heeke, S.; Ilié, M.; Allegra, M.; Vallée, A.; Salacroup, C.; Tanga, V.; Hofman, V.; Rajamani, J.; Lee, M.; Ordinario, E.; et al. Abstract 5299: Detection of ALK fusion transcripts in plasma of non-small cell lung cancer patients using a novel RT-PCR based assay. Exp. Mol. Ther. 2020, 80, 5299. [CrossRef]

48. Heeke, S.; Benzaquen, J.; Hofman, V.; Ilié, M.; Allegra, M.; Long-Mira, E.; Lassalle, S.; Tanga, V.; Salacroup, C.; Bonnetaud, C.; et al. Critical Assessment in Routine Clinical Practice of Liquid Biopsy for EGFR Status Testing in Non-Small-Cell Lung Cancer: A Single-Laboratory Experience (LPCE, Nice, France). Clin. Lung Cancer 2020, 21, 56-65. [CrossRef]

49. Ilie, M.; Juco, J.; Huang, L.; Hofman, V.; Khambata-Ford, S.; Hofman, P. Use of the 22C3 anti-programmed death-ligand 1 antibody to determine programmed death-ligand 1 expression in cytology samples obtained from non-small cell lung cancer patients. Cancer Cytopathol. 2018, 126, 264-274. [CrossRef] [PubMed]

50. Jain, D.; Nambirajan, A.; Borczuk, A.; Chen, G.; Minami, Y.; Moreira, A.L.; Motoi, N.; Papotti, M.; Rekhtman, N.; Russell, P.A.; et al. Immunocytochemistry for predictive biomarker testing in lung cancer cytology. Cancer Cytopathol. 2019, 127, 325-339. [CrossRef]

51. Ilie, M.; Szafer-Glusman, E.; Hofman, V.; Chamorey, E.; Lalvée, S.; Selva, E.; Leroy, S.; Marquette, C.H.; Kowanetz, M.; Hedge, P.; et al. Detection of PD-L1 in circulating tumor cells and white blood cells from patients with advanced non-small-cell lung cancer. Ann. Oncol. 2018, 29, 193-199. [CrossRef]

52. Guibert, N.; Jones, G.; Beeler, J.F.; Plagnol, V.; Morris, C.; Mourlanette, J.; Delaunay, M.; Keller, L.; Rouquette, I.; Favre, G.; et al. Targeted sequencing of plasma cell-free DNA to predict response to PD1 inhibitors in advanced non-small cell lung cancer. Lung Cancer 2019, 137, 1-6. [CrossRef]

53. Dearden, S.; Stevens, J.; Wu, Y.-L.; Blowers, D. Mutation incidence and coincidence in non small-cell lung cancer: Meta-analyses by ethnicity and histology (mutMap). Ann. Oncol. 2013, 24, 2371-2376. [CrossRef]

54. Graham, R.P.; Treece, A.L.; Lindeman, N.I.; Vasalos, P.; Shan, M.; Jennings, L.J.; Rimm, D.L. Worldwide Frequency of Commonly Detected EGFR Mutations. Arch. Pathol. Lab. Med. 2017, 142, 163-167. [CrossRef]

55. Arrieta, O.; Ramírez-Tirado, L.-A.; Báez-Saldaña, R.; Peña-Curiel, O.; Soca-Chafre, G.; Macedo-Perez, E.-O. Different mutation profiles and clinical characteristics among Hispanic patients with non-small cell lung cancer could explain the "Hispanic paradox". Lung Cancer 2015, 90, 161-166. [CrossRef]

56. Gimbrone, N.; Sarcar, B.; Gordian, E.; Rivera, J.; Lopez, C.; Yoder, S.; Teer, J.; Welsh, E.; Chiaporri, A.; Schabath, M.; et al. Somatic Mutations and Ancestry Markers in Hispanic Lung Cancer Patients. J. Thorac. Oncol. 2017, 12, 1541. [CrossRef]

57. Steuer, C.E.; Behera, M.; Berry, L.; Kim, S.; Rossi, M.; Sica, G.; Owonikoko, T.K.; Johnson, B.E.; Kris, M.G.; Bunn, P.A.; et al. Role of race in oncogenic driver prevalence and outcomes in lung adenocarcinoma: Results from the Lung Cancer Mutation Consortium. Cancer 2015, 122, 766-772. [CrossRef] [PubMed]

58. Araujo, L.H.; Lammers, P.E.; Matthews-Smith, V.; Eisenberg, R.; Gonzalez, A.; Schwartz, A.G.; Timmers, C.; Shilo, K.; Zhao, W.; Natarajan, T.G.; et al. Somatic Mutation Spectrum of Non-Small-Cell Lung Cancer in African Americans: A Pooled Analysis. J. Thorac. Oncol. 2015, 10, 1430-1436. [CrossRef] [PubMed]

59. Campbell, J.D.; Lathan, C.; Sholl, L.; Ducar, M.; Vega, M.; Sunkavalli, A.; Lin, L.; Hanna, M.; Schubert, L.; Thorner, A.; et al. Comparison of Prevalence and Types of Mutations in Lung Cancers Among Black and White Populations. JAMA Oncol. 2017, 3 , 801-809. [CrossRef] [PubMed]

60. Lusk, C.M.; Watza, D.; Dyson, G.; Craig, D.B.; Ratliff, V.; Wenzlaff, A.S.; Lonardo, F.; Bollig-Fischer, A.; Bepler, G.; Purrington, K.S.; et al. Profiling the Mutational Landscape in Known Driver Genes and Novel Genes in African American Non-Small Cell Lung Cancer Patients. Clin. Cancer Res. 2019, 25, 4300-4308. [CrossRef]

61. Chougule, A.; Prabhash, K.; Noronha, V.; Joshi, A.; Thavamani, A.; Chandrani, P.; Upadhyay, P.; Utture, S.; Desai, S.; Jambhekar, N.; et al. Frequency of EGFR Mutations in 907 Lung Adenocarcioma Patients of Indian Ethnicity. PLoS ONE 2013, 8, e76164. [CrossRef]

62. Nakra, T.; Mehta, A.; Bal, A.; Nambirajan, A.; Mishra, D.; Midha, D.; Gupta, N.; Arora, N.; Gupta, P.; Gupta, P.; et al. Epidermal growth factor receptor mutation status in pulmonary adenocarcinoma: Multi-institutional data discussion at national conference of "Lung Cancer Management in Indian context". Curr. Probl. Cancer 2020, 44, 100561. [CrossRef]

63. Hofman, V.; Hofman, P. Resistances to EGFR tyrosine kinase inhibitors in lung cancer-How to routinely track them in a molecular pathology laboratory? J. Thorac. Dis. 2019, 11, S65-S70. [CrossRef]

64. Heeke, S.; Hofman, V.; Benzaquen, J.; Otto, J.; Tanga, V.; Zahaf, K.; Allegra, M.; Long-Mira, E.; Lassalle, S.; Marquette, C.-H.; et al. Detection of EGFR Mutations From Plasma of NSCLC Patients Using an Automatic Cartridge-Based PCR System. Front. Pharmacol. 2021, 12, 657743. [CrossRef]

65. Lassalle, S.; Hofman, V.; Heeke, S.; Benzaquen, J.; Long, E.; Poudenx, M.; Lantéri, E.; Boutros, J.; Tanga, V.; Zahaf, K.; et al. Targeted Assessment of the EGFR Status as Reflex Testing in Treatment-Naive Non-Squamous Cell Lung Carcinoma Patients: A Single Laboratory Experience (LPCE, Nice, France). Cancers 2020, 12, 955. [CrossRef] 
66. Tanaka, R.; Ohtsuka, K.; Ogura, W.; Arai, N.; Yoshida, T.; Nakazato, Y.; Tachibana, K.; Takata, S.; Fujiwara, M.; Kamma, H.; et al. Subtyping and EGFR mutation testing from blocks of cytological materials, based on liquid-based cytology for lung cancer at bronchoscopic examinations. Diagn. Cytopathol. 2020, 48, 516-523. [CrossRef]

67. Hofman, P. Next-Generation Sequencing with Liquid Biopsies from Treatment-Naïve Non-Small Cell Lung Carcinoma Patients. Cancers 2021, 13, 2049. [CrossRef]

68. Foggetti, G.; Li, C.; Cai, H.; Hellyer, J.A.; Lin, W.-Y.; Ayeni, D.; Hastings, K.; Choi, J.; Wurtz, A.; Andrejka, L.; et al. Genetic determinants of EGFR-Driven Lung Cancer Growth and Therapeutic Response In Vivo. Cancer Discov. 2021. [CrossRef]

69. Qiao, M.; Jiang, T.; Liu, X.; Mao, S.; Zhou, F.; Li, X.; Zhao, C.; Chen, X.; Su, C.; Ren, S.; et al. Immune checkpoint inhibitors in EGFR-mutated non-small cell lung cancer: Dusk or Dawn? J. Thorac. Oncol. 2021. [CrossRef] [PubMed]

70. Wu, Y.-L.; Tsuboi, M.; He, J.; John, T.; Grohe, C.; Majem, M.; Goldman, J.W.; Laktionov, K.; Kim, S.-W.; Kato, T.; et al. Osimertinib in Resected EGFR-Mutated Non-Small-Cell Lung Cancer. N. Engl. J. Med. 2020, 383, 1711-1723. [CrossRef] [PubMed]

71. Hofman, P. ALK in Non-Small Cell Lung Cancer (NSCLC) Pathobiology, Epidemiology, Detection from Tumor Tissue and Algorithm Diagnosis in a Daily Practice. Cancers 2017, 9, 107. [CrossRef]

72. Hofman, P. Detecting Resistance to Therapeutic ALK Inhibitors in Tumor Tissue and Liquid Biopsy Markers: An Update to a Clinical Routine Practice. Cells 2021, 10, 168. [CrossRef] [PubMed]

73. Jahanzeb, M.; Lin, H.M.; Pan, X.; Yin, Y.; Baumann, P.; Langer, C.J. Immunotherapy Treatment Patterns and Outcomes Among ALK-Positive Patients With Non-Small-Cell Lung Cancer. Clin. Lung Cancer 2021, 22, 49-57. [CrossRef] [PubMed]

74. Hofman, P. ALK Status Assessment with Liquid Biopsies of Lung Cancer Patients. Cancers 2017, 9, 106. [CrossRef]

75. Conde, E.; Rojo, F.; Gómez, J.; Enguita, A.B.; Abdulkader, I.; González, A.; Lozano, D.; Mancheño, N.; Salas, C.; Salido, M.; et al. Molecular diagnosis in non-small-cell lung cancer: Expert opinion on ALK and ROS1 testing. J. Clin. Pathol. 2021. [CrossRef]

76. Hofman, V.; Lassalle, S.; Bence, C.; Long-Mira, E.; Nahon-Estève, S.; Heeke, S.; Lespinet-Fabre, V.; Butori, C.; Ilie, M.; Hofman, P. Any Place for Immunohistochemistry within the Predictive Biomarkers of Treatment in Lung Cancer Patients? Cancers 2018, 10, 70. [CrossRef] [PubMed]

77. Pisapia, P.; Lozano, M.D.; Vigliar, E.; Bellevicine, C.; Pepe, F.; Malapelle, U.; Troncone, G. ALK and ROS1 testing on lung cancer cytologic samples: Perspectives. Cancer Cytopathol. 2017, 125, 817-830. [CrossRef]

78. Roy-Chowdhuri, S. Immunocytochemistry of cytology specimens for predictive biomarkers in lung cancer. Transl. Lung Cancer Res. 2020, 9, 898-905. [CrossRef] [PubMed]

79. Marino, F.Z.; Rossi, G.; Cozzolino, I.; Montella, M.; Micheli, M.; Bogina, G.; Munari, E.; Brunelli, M.; Franco, R. Multiplex fluorescence in situ hybridisation to detect anaplastic lymphoma kinase and ROS proto-oncogene 1 receptor tyrosine kinase rearrangements in lung cancer cytological samples. J. Clin. Pathol. 2019, 73, 96-101. [CrossRef]

80. Amemiya, K.; Hirotsu, Y.; Nagakubo, Y.; Mochizuki, H.; Higuchi, R.; Tsutsui, T.; Kakizaki, Y.; Miyashita, Y.; Oyama, T.; Omata, M. Actionable driver DNA variants and fusion genes can be detected in archived cytological specimens with the Oncomine Dx Target Test Multi-CDx system in lung cancer. Cancer Cytopathol. 2021. [CrossRef] [PubMed]

81. Aguado, C.; Giménez-Capitán, A.; Román, R.; Rodríguez, S.; Jordana-Ariza, N.; Aguilar, A.; Cabrera-Gálvez, C.; Rivas-Corredor, C.; Lianes, P.; Viteri, S.; et al. RNA-Based Multiplexing Assay for Routine Testing of Fusion and Splicing Variants in Cytological Samples of NSCLC Patients. Diagnostics 2020, 11, 15. [CrossRef]

82. Alidousty, C.; Duerbaum, N.; Wagener-Ryczek, S.; Baar, T.; Martelotto, L.G.; Heydt, C.; Siemanowski, J.; Holz, B.; Binot, E.; Fassunke, J.; et al. Prevalence and potential biological role of TERT amplifications in ALK translocated adenocarcinoma of the lung. Histopathology 2021, 78, 578-585. [CrossRef]

83. Drilon, A.; Jenkins, C.; Iyer, S.; Schoenfeld, A.; Keddy, C.; Davare, M.A. ROS1-dependent cancers-biology, diagnostics and therapeutics. Nat. Rev. Clin. Oncol. 2021, 18, 35-55. [CrossRef] [PubMed]

84. Landi, L.; Cappuzzo, F. How selecting best upfront therapy for metastatic disease?-Focus on ROS1-rearranged disease. Transl. Lung Cancer Res. 2020, 9, 2686-2695. [CrossRef]

85. Hofman, V.; Rouquette, I.; Long-Mira, E.; Piton, N.; Chamorey, E.; Heeke, S.; Vignaud, J.M.; Yguel, C.; Mazières, J.; Lepage, A.-L.; et al. Multicenter Evaluation of a Novel ROS1 Immunohistochemistry Assay (SP384) for Detection of ROS1 Rearrangements in a Large Cohort of Lung Adenocarcinoma Patients. J. Thorac. Oncol. 2019, 14, 1204-1212. [CrossRef]

86. Roviello, G.; D’Angelo, A.; Sirico, M.; Pittacolo, M.; Conter, F.U.; Sobhani, N. Advances in anti-BRAF therapies for lung cancer. Investig. N. Drugs 2021, 39, 879-890. [CrossRef]

87. Carneiro, J.G.; Couto, P.G.; Bastos-Rodrigues, L.; Bicalho, M.A.C.; Vidigal, P.V.; Vilhena, A.; Amaral, N.F.; Bale, A.E.; Friedman, E.; De Marco, L. Spectrum of somatic EGFR, KRAS, BRAF, PTEN mutations and TTF-1 expression in Brazilian lung cancer patients. Genet. Res. 2014, 96, 2. [CrossRef]

88. Hofman, V.; Benzaquen, J.; Heeke, S.; Lassalle, S.; Poudenx, M.; Long, E.; Lantéri, E.; Bordone, O.; Lespinet, V.; Tanga, V.; et al. Real-world assessment of the BRAF status in non-squamous cell lung carcinoma using VE1 immunohistochemistry: A single laboratory experience (LPCE, Nice, France). Lung Cancer 2020, 145, 58-62. [CrossRef]

89. Jain, D.; Roy-Chowdhuri, S. Molecular Pathology of Lung Cancer Cytology Specimens: A Concise Review. Arch. Pathol. Lab. Med. 2018, 142, 1127-1133. [CrossRef]

90. Iaccarino, A.; Pisapia, P.; Pepe, F.; Sgariglia, R.; Nacchio, M.; Russo, G.; Gragnano, G.; De Luca, C.; Troncone, G.; Malapelle, U. Liquid biopsy for BRAF mutations testing in non-small cell lung cancer: A retrospective study. J. Clin. Pathol. 2020. [CrossRef] 
91. Amatu, A.; Sartore-Bianchi, A.; Siena, S. NTRK gene fusions as novel targets of cancer therapy across multiple tumour types. ESMO Open 2016, 1, 000023. [CrossRef] [PubMed]

92. Amatu, A.; Sartore-Bianchi, A.; Bencardino, K.; Pizzutilo, E.; Tosi, F.; Siena, S. Tropomyosin receptor kinase (TRK) biology and the role of NTRK gene fusions in cancer. Ann. Oncol. 2019, 30, 5-15. [CrossRef] [PubMed]

93. Chetty, R. Neurotrophic tropomyosin or tyrosine receptor kinase (NTRK) genes. J. Clin. Pathol. 2019, 72, 187-190. [CrossRef] [PubMed]

94. Farago, A.F.; Taylor, M.S.; Doebele, R.C.; Zhu, V.W.; Kummar, S.; Spira, A.I.; Boyle, T.A.; Haura, E.B.; Arcila, M.E.; Benayed, R.; et al. Clinicopathologic Features of Non-Small-Cell Lung Cancer Harboring an NTRK Gene Fusion. JCO Precis. Oncol. 2018, 18, 37. [CrossRef]

95. Li, H.; Yan, S.; Liu, Y.; Ma, L.; Liu, X.; Liu, Y.; Cheng, Y. Analysis of NTRK mutation and clinicopathologic factors in lung cancer patients in northeast China. Int. J. Biol. Markers 2020, 35, 36-40. [CrossRef]

96. Si, X.; Pan, R.; Ma, S.; Li, L.; Liang, L.; Zhang, P.; Chu, Y.; Wang, H.; Wang, M.; Zhang, X.; et al. Genomic characteristics of driver genes in Chinese patients with non-small cell lung cancer. Thorac. Cancer 2021, 12, 357-363. [CrossRef]

97. Volckmar, A.-L.; Christopoulos, P.; Kirchner, M.; Allgäuer, M.; Neumann, O.; Budczies, J.; Rempel, E.; Horak, P.; Glade, J.; Goldschmid, H.; et al. Targeting rare and non-canonical driver variants in NSCLC-An uncharted clinical field. Lung Cancer 2021, 154, 131-141. [CrossRef]

98. Cocco, E.; Scaltriti, M.; Drilon, A. NTRK fusion-positive cancers and TRK inhibitor therapy. Nat. Rev. Clin. Oncol. 2018, 15, 731-747. [CrossRef]

99. Doebele, R.C.; Drilon, A.; Paz-Ares, L.; Siena, S.; Shaw, A.T.; Farago, A.F.; Blakely, C.M.; Seto, T.; Cho, B.C.; Tosi, D.; et al. Entrectinib in patients with advanced or metastatic NTRK fusion-positive solid tumours: Integrated analysis of three phase 1-2 trials. Lancet Oncol. 2020, 21, 271-282. [CrossRef]

100. Drilon, A. TRK inhibitors in TRK fusion-positive cancers. Ann. Oncol. 2019, 30, 23-30. [CrossRef] [PubMed]

101. Haratake, N.; Seto, T. NTRK Fusion-positive Non-small-cell Lung Cancer: The Diagnosis and Targeted Therapy. Clin. Lung Cancer 2021, 22, 1-5. [CrossRef] [PubMed]

102. Huang, F.W.; Feng, F.Y. A Tumor-Agnostic NTRK (TRK) Inhibitor. Cell 2019, 177, 8. [CrossRef] [PubMed]

103. Ricciuti, B.; Brambilla, M.; Metro, G.; Baglivo, S.; Matocci, R.; Pirro, M.; Chiari, R. Targeting NTRK fusion in non-small cell lung cancer: Rationale and clinical evidence. Med. Oncol. 2017, 34, 105. [CrossRef]

104. Rolfo, C. NTRK gene fusions: A rough diamond ready to sparkle. Lancet Oncol. 2020, 21, 472-474. [CrossRef]

105. Sartore-Bianchi, A.; Pizzutilo, E.G.; Marrapese, G.; Tosi, F.; Cerea, G.; Siena, S. Entrectinib for the treatment of metastatic NSCLC: Safety and efficacy. Expert Rev. Anticancer. Ther. 2020, 20, 333-341. [CrossRef] [PubMed]

106. Yoshino, T.; Pentheroudakis, G.; Mishima, S.; Overman, M.; Yeh, K.-H.; Baba, E.; Naito, Y.; Calvo, F.; Saxena, A.; Chen, L.-T.; et al. JSCO_ESMO_ASCO_JSMO_TOS: International expert consensus recommendations for tumour-agnostic treatments in patients with solid tumours with microsatellite instability or NTRK fusions. Ann. Oncol. 2020, 31, 861-872. [CrossRef]

107. Rozlytrek. Available online: https://www.ema.europa.eu/en/medicines/human/EPAR/rozlytrek (accessed on 10 April 2021).

108. Vitrakvi. Available online: https://www.ema.europa.eu/en/medicines/human/EPAR/vitrakvi (accessed on 10 April 2021).

109. Matter, M.S.; Chijioke, O.; Savic, S.; Bubendorf, L. Narrative review of molecular pathways of kinase fusions and diagnostic approaches for their detection in non-small cell lung carcinomas. Transl. Lung Cancer Res. 2020, 9, 2645-2655. [CrossRef] [PubMed]

110. Conde, E.; Hernandez, S.; Sanchez, E.; Regojo, R.M.; Camacho, C.; Alonso, M.; Martinez, R.; Lopez-Rios, F. Pan-TRK Immunohistochemistry. Arch. Pathol. Lab. Med. 2020. [CrossRef] [PubMed]

111. De Luca, C.; Pepe, F.; Iaccarino, A.; Pisapia, P.; Righi, L.; Listì, A.; Greco, L.; Gragnano, G.; Campione, S.; De Dominicis, G.; et al. RNA-Based Assay for Next-Generation Sequencing of Clinically Relevant Gene Fusions in Non-Small Cell Lung Cancer. Cancers 2021, 13, 139. [CrossRef]

112. Abi-Raad, R.; Prasad, M.L.; Adeniran, A.J.; Cai, G. Fine-needle aspiration cytomorphology of papillary thyroid carcinoma withNTRKgene rearrangement from a case series with predominantly indeterminate cytology. Cancer Cytopathol. 2020, 128, 803-811. [CrossRef]

113. Hrudka, J.; Drozenová, J.; Sýba, J.; Gregová, M.; Dundr, P. Secretory carcinoma of salivary type in a lymph node presenting as a neck cyst diagnosed by cytology: A case report. Diagn. Cytopathol. 2021, 49, 1-6. [CrossRef]

114. Labourier, E.; Fahey, T.J. Preoperative molecular testing in thyroid nodules with Bethesda VI cytology: Clinical experience and review of the literature. Diagn. Cytopathol. 2021, 49, 175-180. [CrossRef]

115. Ramani, N.S.; Chen, H.; Broaddus, R.R.; Lazar, A.J.; Luthra, R.; Medeiros, L.J.; Patel, K.P.; Rashid, A.; Routbort, M.J.; Stewart, J.; et al. Utilization of cytology smears improves success rates of RNA-based next-generation sequencing gene fusion assays for clinically relevant predictive biomarkers. Cancer Cytopathol. 2021, 129, 374-382. [CrossRef]

116. De Winne, K.; Sorber, L.; Lambin, S.; Siozopoulou, V.; Beniuga, G.; Dedeurwaerdere, F.; D’Haene, N.; Habran, L.; Libbrecht, L.; Van Huysse, J.; et al. Immunohistochemistry as a screening tool for NTRK gene fusions: Results of a first Belgian ring trial. Virchows Arch. 2021, 478, 283-291. [CrossRef]

117. Elfving, H.; Broström, E.; Moens, L.N.; Almlöf, J.; Cerjan, D.; Lauter, G.; Nord, H.; Mattsson, J.S.; Ullenhag, G.J.; Strell, C.; et al. Evaluation of NTRK immunohistochemistry as a screening method for NTRK gene fusion detection in non-small cell lung cancer. Lung Cancer 2021, 151, 53-59. [CrossRef] [PubMed] 
118. Heidrich, I.; Ačkar, L.; Mohammadi, P.M.; Pantel, K. Liquid biopsies: Potential and challenges. Int. J. Cancer 2021, 148, 528-545. [CrossRef] [PubMed]

119. Herbst, R.S.; Aisner, D.L.; Sonett, J.R.; Turk, A.T.; Weintraub, J.L.; Lindeman, N.I. Practical Considerations Relating to Routine Clinical Biomarker Testing for Non-small Cell Lung Cancer: Focus on Testing for RET Fusions. Front. Med. 2021, 7, 562480. [CrossRef]

120. Hsiao, S.J.; Zehir, A.; Sireci, A.N.; Aisner, D.L. Detection of Tumor NTRK Gene Fusions to Identify Patients Who May Benefit from Tyrosine Kinase (TRK) Inhibitor Therapy. J. Mol. Diagn. 2019, 21, 553-571. [CrossRef] [PubMed]

121. Kirchner, M.; Glade, J.; Lehmann, U.; Merkelbach-Bruse, S.; Hummel, M.; Lehmann, A.; Trautmann, M.; Kumbrink, J.; Jung, A.; Dietmaier, W.; et al. NTRK testing: First results of the QuiP-EQA scheme and a comprehensive map of NTRK fusion variants and their diagnostic coverage by targeted RNA-based NGS assays. Genes Chromosom. Cancer 2020, 59, 445-453. [CrossRef]

122. Marchio', C.; Scaltriti, M.; Ladanyi, M.; Iafrate, A.; Bibeau, F.; Dietel, M.; Hechtman, J.; Troiani, T.; López-Rios, F.; Douillard, J.-Y.; et al. ESMO recommendations on the standard methods to detect NTRK fusions in daily practice and clinical research. Ann. Oncol. 2019, 30, 1417-1427. [CrossRef]

123. Pfarr, N.; Kirchner, M.; Lehmann, U.; Leichsenring, J.; Merkelbach-Bruse, S.; Glade, J.; Hummel, M.; Stögbauer, F.; Lehmann, A.; Trautmann, M.; et al. Testing NTRK testing: Wet-lab and in silico comparison of RNA-based targeted sequencing assays. Genes Chromosomes Cancer 2020, 59, 178-188. [CrossRef]

124. Solomon, J.P.; Linkov, I.; Rosado, A.; Mullaney, K.; Rosen, E.Y.; Frosina, D.; Jungbluth, A.A.; Zehir, A.; Benayed, R.; Drilon, A.; et al. NTRK fusion detection across multiple assays and 33,997 cases: Diagnostic implications and pitfalls. Mod. Pathol. 2020, 33, 38-46. [CrossRef]

125. Gautschi, O.; Bubendorf, L.; Leyvraz, S.; Menon, R.; Diebold, J. Challenges in the Diagnosis of NTRK Fusion-Positive Cancers. J. Thorac. Oncol. 2020, 15, 108-110. [CrossRef]

126. Gatalica, Z.; Xiu, J.; Swensen, J.; Vranic, S. Molecular characterization of cancers with NTRK gene fusions. Mod. Pathol. 2019, 32, 147-153. [CrossRef]

127. Hechtman, J.F.; Benayed, R.; Hyman, D.M.; Drilon, A.; Zehir, A.; Frosina, D.; Arcila, M.E.; Dogan, S.; Klimstra, D.S.; Ladanyi, M.; et al. Pan-Trk Immunohistochemistry Is an Efficient and Reliable Screen for the Detection of NTRK Fusions. Am. J. Surg. Pathol. 2017, 41, 1547-1551. [CrossRef] [PubMed]

128. Hung, Y.P.; Sholl, L.M. Diagnostic and Predictive Immunohistochemistry for Non-Small Cell Lung Carcinomas. Adv. Anat. Pathol. 2018, 25, 374-386. [CrossRef] [PubMed]

129. Solomon, J.P.; Hechtman, J.F. Detection of NTRK Fusions: Merits and Limitations of Current Diagnostic Platforms. Cancer Res. 2019, 79, 3163-3168. [CrossRef]

130. Bruno, R.; Fontanini, G. Next Generation Sequencing for Gene Fusion Analysis in Lung Cancer: A Literature Review. Diagnostics 2020, 10, 521. [CrossRef]

131. Kato, S.; Subbiah, V.; Marchlik, E.; Elkin, S.K.; Carter, J.L.; Kurzrock, R. RET Aberrations in Diverse Cancers: Next-Generation Sequencing of 4871 Patients. Clin. Cancer Res. 2017, 23, 1988-1997. [CrossRef]

132. Platt, A.; Morten, J.; Ji, Q.; Elvin, P.; Womack, C.; Su, X.; Donald, E.; Gray, N.; Read, J.; Bigley, G.; et al. A retrospective analysis of RET translocation, gene copy number gain and expression in NSCLC patients treated with vandetanib in four randomized Phase III studies. BMC Cancer 2015, 15, 171. [CrossRef] [PubMed]

133. Li, W.; Guo, L.; Liu, Y.; Dong, L.; Yang, L.; Chen, L.; Liu, K.; Shao, Y.; Ying, J. Potential Unreliability of Uncommon ALK, ROS1, and RET Genomic Breakpoints in Predicting the Efficacy of Targeted Therapy in NSCLC. J. Thorac. Oncol. 2021, 16, 404-418. [CrossRef] [PubMed]

134. Karlsson, A.; Cirenajwis, H.; Ericson-Lindquist, K.; Brunnström, H.; Reuterswärd, C.; Jönsson, M.; Ortiz-Villalón, C.; Hussein, A.; Bergman, B.; Vikström, A.; et al. A combined gene expression tool for parallel histological prediction and gene fusion detection in non-small cell lung cancer. Sci. Rep. 2019, 9, 5207. [CrossRef]

135. Wang, R.; Pan, Y.; Li, C.; Zhang, H.; Garfield, D.; Li, Y.; Ye, T.; Hu, H.; Luo, X.; Li, H.; et al. Analysis of Major Known Driver Mutations and Prognosis in Resected Adenosquamous Lung Carcinomas. J. Thorac. Oncol. 2014, 9, 760-768. [CrossRef] [PubMed]

136. Ferrara, R.; Auger, N.; Auclin, E.; Besse, B. Clinical and Translational Implications of RET Rearrangements in Non-Small Cell Lung Cancer. J. Thorac. Oncol. 2018, 13, 27-45. [CrossRef] [PubMed]

137. Offin, M.; Guo, R.; Wu, S.L.; Sabari, J.; Land, J.D.; Ni, A.; Montecalvo, J.; Halpenny, D.F.; Buie, L.W.; Pak, T.; et al. Immunophenotype and Response to Immunotherapy of RET-Rearranged Lung Cancers. JCO Precis. Oncol. 2019, 3, 1-8. [CrossRef] [PubMed]

138. Liu, J.; Liu, Y. Molecular diagnostic characteristics based on the next generation sequencing in lung cancer and its relationship with the expression of PD-L. Pathol. Res. Pract. 2020, 216, 152797. [CrossRef] [PubMed]

139. Mizukami, T.; Shiraishi, K.; Shimada, Y.; Ogiwara, H.; Tsuta, K.; Ichikawa, H.; Sakamoto, H.; Kato, M.; Shibata, T.; Nakano, T.; et al. Molecular Mechanisms Underlying Oncogenic RET Fusion in Lung Adenocarcinoma. J. Thorac. Oncol. 2014, 9, 622-630. [CrossRef]

140. Belli, C.; Anand, S.; Gainor, J.F.; Penault-Llorca, F.; Subbiah, V.; Drilon, A.; Andrè, F.; Curigliano, G. Progresses Toward Precision Medicine in RET-altered Solid Tumors. Clin. Cancer Res. 2020, 26, 6102-6111. [CrossRef]

141. Choudhury, N.J.; Drilon, A. Decade in review: A new era for RET-rearranged lung cancers. Transl. Lung Cancer Res. 2020, 9 , 2571-2580. [CrossRef] 
142. Drilon, A.; Lin, J.J.; Filleron, T.; Ni, A.; Milia, J.; Bergagnini, I.; Hatzoglou, V.; Velcheti, V.; Offin, M.; Li, B.; et al. Frequency of Brain Metastases and Multikinase Inhibitor Outcomes in Patients With RET-Rearranged Lung Cancers. J. Thorac. Oncol. 2018, 13, 1595-1601. [CrossRef] [PubMed]

143. Drilon, A.; Hu, Z.I.; Lai, G.G.Y.; Tan, D.S.W. Targeting RET-driven cancers: Lessons from evolving preclinical and clinical landscapes. Nat. Rev. Clin. Oncol. 2018, 15, 151-167. [CrossRef] [PubMed]

144. Drusbosky, L.M.; Rodriguez, E.; Dawar, R.; Ikpeazu, C.V. Therapeutic strategies in RET gene rearranged non-small cell lung cancer. J. Hematol. Oncol. 2021, 14, 50. [CrossRef]

145. Jia, C.-C.; Chen, W.; Feng, Z.-L.; Liu, Z.-P. Recent developments of RET protein kinase inhibitors with diverse scaffolds as hinge binders. Futur. Med. Chem. 2021, 13, 45-62. [CrossRef] [PubMed]

146. Subbiah, V.; Yang, D.; Velcheti, V.; Drilon, A.; Meric-Bernstam, F. State-of-the-Art Strategies for Targeting RET-Dependent Cancers. J. Clin. Oncol. 2020, 38, 1209-1221. [CrossRef] [PubMed]

147. Subbiah, V.; Cote, G.J. Advances in Targeting RET-Dependent Cancers. Cancer Discov. 2020, 10, 498-505. [CrossRef]

148. Baglivo, S.; Ludovini, V.; Moretti, R.; Bellezza, G.; Sidoni, A.; Roila, F.; Metro, G. RET Rearrangement as a Predictor of Unresponsiveness to Immunotherapy in Non-Small Cell Lung Cancer: Report of Two Cases with Review of the Literature. Oncol. Ther. 2020, 8, 333-339. [CrossRef]

149. Hegde, A.; Andreev-Drakhlin, A.Y.; Roszik, J.; Huang, L.; Liu, S.; Hess, K.; Cabanillas, M.; Hu, M.I.; Busaidy, N.L.; Sherman, S.I.; et al. Responsiveness to immune checkpoint inhibitors versus other systemic therapies in RET-aberrant malignancies. ESMO Open 2020, 5, 000799. [CrossRef] [PubMed]

150. Belli, C.; Penault-Llorca, F.; Ladanyi, M.; Normanno, N.; Scoazec, J.-Y.; Lacroix, L.; Reis-Filho, J.; Subbiah, V.; Gainor, J.; Endris, V.; et al. ESMO recommendations on the standard methods to detect RET fusions and mutations in daily practice and clinical research. Ann. Oncol. 2021, 32, 337-350. [CrossRef] [PubMed]

151. Yatabe, Y.; Dacic, S.; Borczuk, A.C.; Warth, A.; Russell, P.A.; Lantuejoul, S.; Beasley, M.B.; Thunnissen, E.; Pelosi, G.; Rekhtman, N.; et al. Best Practices Recommendations for Diagnostic Immunohistochemistry in Lung Cancer. J. Thorac. Oncol. 2019, 14, 377-407. [CrossRef]

152. Alì, G.; Bruno, R.; Savino, M.; Giannini, R.; Pelliccioni, S.; Menghi, M.; Boldrini, L.; Proietti, A.; Chella, A.; Ribechini, A.; et al. Analysis of Fusion Genes by NanoString System: A Role in Lung Cytology? Arch. Pathol. Lab. Med. 2018, 142, 480-489. [CrossRef]

153. Tan, A.C.; Seet, A.O.; Lai, G.G.; Lim, T.H.; Lim, A.S.; Tan, G.S.; Takano, A.; Tai, D.W.-M.; Tan, T.J.; Lam, J.Y.; et al. Molecular Characterization and Clinical Outcomes in RET-Rearranged NSCLC. J. Thorac. Oncol. 2020, 15, 1928-1934. [CrossRef]

154. Benayed, R.; Offin, M.; Mullaney, K.; Sukhadia, P.; Rios, K.; Desmeules, P.; Ptashkin, R.; Won, H.; Chang, J.; Halpenny, D.; et al. High Yield of RNA Sequencing for Targetable Kinase Fusions in Lung Adenocarcinomas with No Mitogenic Driver Alteration Detected by DNA Sequencing and Low Tumor Mutation Burden. Clin. Cancer Res. 2019, 25, 4712-4722. [CrossRef]

155. Esagian, S.M.; Grigoriadou, G.I.; Nikas, I.P.; Boikou, V.; Sadow, P.M.; Won, J.-K.; Economopoulos, K.P. Comparison of liquid-based to tissue-based biopsy analysis by targeted next generation sequencing in advanced non-small cell lung cancer: A comprehensive systematic review. J. Cancer Res. Clin. Oncol. 2020, 146, 2051-2066. [CrossRef]

156. Supplee, J.G.; Milan, M.S.; Lim, L.P.; Potts, K.T.; Sholl, L.M.; Oxnard, G.R.; Paweletz, C.P. Sensitivity of next-generation sequencing assays detecting oncogenic fusions in plasma cell-free DNA. Lung Cancer 2019, 134, 96-99. [CrossRef] [PubMed]

157. Vuong, H.G.; Ho, A.T.N.; Altibi, A.M.; Nakazawa, T.; Katoh, R.; Kondo, T. Clinicopathological implications of MET exon 14 mutations in non-small cell lung cancer-A systematic review and meta-analysis. Lung Cancer 2018, 123, 76-82. [CrossRef] [PubMed]

158. Paik, P.K.; Felip, E.; Veillon, R.; Sakai, H.; Cortot, A.B.; Garassino, M.C.; Mazieres, J.; Viteri, S.; Senellart, H.; Van Meerbeeck, J.; et al. Tepotinib in Non-Small-Cell Lung Cancer with MET Exon 14 Skipping Mutations. N. Engl. J. Med. 2020, 383, 931-943. [CrossRef] [PubMed]

159. Wolf, J.; Seto, T.; Han, J.-Y.; Reguart, N.; Garon, E.B.; Groen, H.J.; Tan, D.S.; Hida, T.; de Jonge, M.; Orlov, S.V.; et al. Capmatinib inMETExon 14-Mutated orMET-Amplified Non-Small-Cell Lung Cancer. N. Engl. J. Med. 2020, 383, 944-957. [CrossRef]

160. Wu, Y.-L.; Smit, E.F.; Bauer, T.M. Capmatinib for patients with non-small cell lung cancer with MET exon 14 skipping mutations: A review of preclinical and clinical studies. Cancer Treat. Rev. 2021, 95, 102173. [CrossRef] [PubMed]

161. Hong, L.; Zhang, J.; Heymach, J.V.; Le, X. Current and future treatment options for MET exon 14 skipping alterations in non-small cell lung cancer. Ther. Adv. Med. Oncol. 2021. [CrossRef] [PubMed]

162. Guibert, N.; Ilie, M.; Long, E.; Hofman, V.; Bouhlel, L.; Brest, P.; Mograbi, B.; Marquette, C.H.; Didier, A.; Mazieres, J.; et al. KRAS Mutations in Lung Adenocarcinoma: Molecular and Epidemiological Characteristics, Methods for Detection, and Therapeutic Strategy Perspectives. Curr. Mol. Med. 2015, 15, 418-432. [CrossRef]

163. McQuitty, E.; Zhang, W.; Hendrickson, H.; Tio, F.O.; Jagirdar, J.; Olsen, R.; Cagle, P.T. Lung Adenocarcinoma Biomarker Incidence in Hispanic Versus Non-Hispanic White Patients. Arch. Pathol. Lab. Med. 2013, 138, 390-394. [CrossRef] [PubMed]

164. El Osta, B.; Behera, M.; Kim, S.; Berry, L.D.; Sica, G.; Pillai, R.N.; Owonikoko, T.K.; Kris, M.G.; Johnson, B.E.; Kwiatkowski, D.J.; et al. Characteristics and Outcomes of Patients With Metastatic KRAS-Mutant Lung Adenocarcinomas: The Lung Cancer Mutation Consortium Experience. J. Thorac. Oncol. 2019, 14, 876-889. [CrossRef]

165. Griesinger, F.; Eberhardt, W.; Nusch, A.; Reiser, M.; Zahn, M.O.; Maintz, C.; Bernhardt, C.; Losem, C.; Stenzinger, A.; Heukamp, L.C.; et al. Biomarker testing in non-small cell lung cancer in routine care: Analysis of the first 3,717 patients in the German prospective, observational, nation-wide CRISP Registry (AIO-TRK-0315). Lung Cancer 2021, 152, 174-184. [CrossRef] [PubMed] 
166. Liu, S.-Y.; Sun, H.; Zhou, J.-Y.; Jie, G.-L.; Xie, Z.; Shao, Y.; Zhang, X.; Ye, J.-Y.; Chen, C.-X.; Zhang, X.-C.; et al. Clinical characteristics and prognostic value of the KRAS G12C mutation in Chinese non-small cell lung cancer patients. Biomark. Res. $2020,8,22$. [CrossRef] [PubMed]

167. Barlesi, F.; Mazieres, J.; Merlio, J.-P.; Debieuvre, D.; Mosser, J.; Lena, H.; Ouafik, L.H.; Besse, B.; Rouquette, I.; Westeel, V.; et al. Routine molecular profiling of patients with advanced non-small-cell lung cancer: Results of a 1-year nationwide programme of the French Cooperative Thoracic Intergroup (IFCT). Lancet 2016, 387, 1415-1426. [CrossRef]

168. Nadal, E.; Chen, G.; Prensner, J.R.; Shiratsuchi, H.; Sam, C.; Zhao, L.; Kalemkerian, G.P.; Brenner, D.; Lin, J.; Reddy, R.M.; et al. KRAS-G12C Mutation Is Associated with Poor Outcome in Surgically Resected Lung Adenocarcinoma. J. Thorac. Oncol. 2014, 9 , 1513-1522. [CrossRef]

169. Gao, G.; Liao, W.; Ma, Q.; Zhang, B.; Chen, Y.; Wang, Y. KRAS G12D mutation predicts lower TMB and drives immune suppression in lung adenocarcinoma. Lung Cancer 2020, 149, 41-45. [CrossRef]

170. Lindsay, C.; Jamal-Hanjani, M.; Forster, M.; Blackhall, F. KRAS: Reasons for optimism in lung cancer. Eur. J. Cancer 2018, 99, 20-27. [CrossRef]

171. Arbour, K.C.; Rizvi, H.; Plodkowski, A.J.; Hellmann, M.D.; Knezevic, A.; Heller, G.; Yu, H.A.; Ladanyi, M.; Kris, M.G.; Arcila, M.E.; et al. Treatment Outcomes and Clinical Characteristics of Patients with KRAS-G12C-Mutant Non-Small Cell Lung Cancer. Clin. Cancer Res. 2021, 27, 2209-2215. [CrossRef]

172. Aredo, J.V.; Padda, S.K. Management of KRAS-Mutant Non-Small Cell Lung Cancer in the Era of Precision Medicine. Curr. Treat. Options Oncol. 2018, 19, 43. [CrossRef]

173. Burns, T.F.; Borghaei, H.; Ramalingam, S.S.; Mok, T.S.; Peters, S. Targeting KRAS-Mutant Non-Small-Cell Lung Cancer: One Mutation at a Time, With a Focus on KRAS G12C Mutations. J. Clin. Oncol. 2020, 38, 4208-4218. [CrossRef] [PubMed]

174. Cagir, A.; Azmi, A.S. KRASG12C inhibitors on the horizon. Futur. Med. Chem. 2019, 11, 923-925. [CrossRef]

175. Canon, J.; Rex, K.; Saiki, A.Y.; Mohr, C.; Cooke, K.; Bagal, D.; Gaida, K.; Holt, T.; Knutson, C.G.; Koppada, N.; et al. The clinical KRAS(G12C) inhibitor AMG 510 drives anti-tumour immunity. Nature 2019, 575, 217-223. [CrossRef] [PubMed]

176. Christensen, J.G.; Olson, P.; Briere, T.; Wiel, C.; Bergo, M.O. Targeting Kras g12c -mutant cancer with a mutation-specific inhibitor. J. Intern. Med. 2020, 288, 183-191. [CrossRef] [PubMed]

177. Elez, F.E.; Tabernero, J. The Effective Targeting of KRASG12C Elusiveness. Cancer Cell 2020, 38, 785-787. [CrossRef] [PubMed]

178. Fedele, C.; Li, S.; Teng, K.W.; Foster, C.J.; Peng, D.; Ran, H.; Mita, P.; Geer, M.J.; Hattori, T.; Koide, A.; et al. SHP2 inhibition diminishes KRASG12C cycling and promotes tumor microenvironment remodeling. J. Exp. Med. 2021, 218, 20201414. [CrossRef]

179. Ferrer, I.; Zugazagoitia, J.; Herbertz, S.; John, W.; Paz-Ares, L.; Schmid-Bindert, G. KRAS-Mutant non-small cell lung cancer: From biology to therapy. Lung Cancer 2018, 124, 53-64. [CrossRef] [PubMed]

180. Ghimessy, A.; Radeczky, P.; Laszlo, V.; Hegedus, B.; Renyi-Vamos, F.; Fillinger, J.; Klepetko, W.; Lang, C.; Dome, B.; Megyesfalvi, Z. Current therapy of KRAS-mutant lung cancer. Cancer Metastasis Rev. 2020, 39, 1159-1177. [CrossRef]

181. Hallin, J.; Engstrom, L.D.; Hargis, L.; Calinisan, A.; Aranda, R.; Briere, D.M.; Sudhakar, N.; Bowcut, V.; Baer, B.R.; Ballard, J.A.; et al. The KRAS(G12C) Inhibitor MRTX849 Provides Insight toward Therapeutic Susceptibility of KRAS-Mutant Cancers in Mouse Models and Patients. Cancer Discov. 2020, 10, 54-71. [CrossRef]

182. Hong, D.S.; Fakih, M.G.; Strickler, J.H.; Desai, J.; Durm, G.A.; Shapiro, G.I.; Falchook, G.S.; Price, T.J.; Sacher, A.; Denlinger, C.S.; et al. KRASG12C Inhibition with Sotorasib in Advanced Solid Tumors. N. Engl. J. Med. 2020, 383, 1207-1217. [CrossRef]

183. Kettle, J.G.; Cassar, D.J. Covalent inhibitors of the GTPase KRASG12C: A review of the patent literature. Expert Opin. Ther. Pat. 2020, 30, 103-120. [CrossRef]

184. Kim, D.; Xue, J.Y.; Lito, P. Targeting KRAS(G12C): From Inhibitory Mechanism to Modulation of Antitumor Effects in Patients. Cell 2020, 183, 850-859. [CrossRef]

185. Klempner, S.J.; Hata, A.N. Can the Help Match the Hype? KRASG12C-Specific Inhibitors and Beyond. Cancer Discov. 2020, 10, 20-22. [CrossRef]

186. Janes, M.R.; Zhang, J.; Li, L.-S.; Hansen, R.; Peters, U.; Guo, X.; Chen, Y.; Babbar, A.; Firdaus, S.J.; Darjania, L.; et al. Targeting KRAS Mutant Cancers with a Covalent G12C-Specific Inhibitor. Cell 2018, 172, 578-589. [CrossRef] [PubMed]

187. Lanman, B.A.; Allen, J.R.; Allen, J.G.; Amegadzie, A.K.; Ashton, K.S.; Booker, S.K.; Chen, J.J.; Chen, N.; Frohn, M.J.; Goodman, G.; et al. Discovery of a Covalent Inhibitor of KRASG12C (AMG 510) for the Treatment of Solid Tumors. J. Med. Chem. 2019, 63, 52-65. [CrossRef] [PubMed]

188. Moore, A.R.; Rosenberg, S.C.; McCormick, F.; Malek, S. RAS-targeted therapies: Is the undruggable drugged? Nat. Rev. Drug Discov. 2020, 19, 533-552. [CrossRef]

189. Nagasaka, M.; Li, Y.; Sukari, A.; Ou, S.-H.I.; Al-Hallak, M.N.; Azmi, A.S. KRAS G12C Game of Thrones, which direct KRAS inhibitor will claim the iron throne? Cancer Treat. Rev. 2020, 84, 101974. [CrossRef] [PubMed]

190. Passiglia, F.; Malapelle, U.; Del Re, M.; Righi, L.; Pagni, F.; Furlan, D.; Danesi, R.; Troncone, G.; Novello, S. KRAS inhibition in non-small cell lung cancer: Past failures, new findings and upcoming challenges. Eur. J. Cancer 2020, 137, 57-68. [CrossRef]

191. Seton-Rogers, S. KRAS-G12C in the crosshairs. Nat. Rev. Cancer 2019, 20, 3. [CrossRef]

192. Salgia, R.; Pharaon, R.; Mambetsariev, I.; Nam, A.; Sattler, M. The improbable targeted therapy: KRAS as an emerging target in non-small cell lung cancer (NSCLC). Cell Rep. Med. 2021, 2, 100186. [CrossRef]

193. Thein, K.Z.; Biter, A.B.; Hong, D.S. Therapeutics Targeting Mutant KRAS. Annu. Rev. Med. 2021, 72, 349-364. [CrossRef] [PubMed]

194. Uprety, D.; Adjei, A.A. KRAS: From undruggable to a druggable Cancer Target. Cancer Treat. Rev. 2020, 89, 102070. [CrossRef] 
195. Xu, K.; Park, D.; Magis, A.T.; Zhang, J.; Zhou, W.; Sica, G.L.; Ramalingam, S.S.; Curran, W.J.; Deng, X. Small Molecule KRAS Agonist for Mutant KRAS Cancer Therapy. Mol. Cancer 2019, 18, 85. [CrossRef]

196. Jones, G.D.; Caso, R.; Tan, K.S.; Mastrogiacomo, B.; Sanchez-Vega, F.; Liu, Y.; Connolly, J.G.; Murciano-Goroff, Y.R.; Bott, M.J.; Adusumilli, P.S.; et al. KRASG12C Mutation Is Associated with Increased Risk of Recurrence in Surgically Resected Lung Adenocarcinoma. Clin. Cancer Res. 2021, 27, 2604-2612. [CrossRef]

197. Nacchio, M.; Sgariglia, R.; Gristina, V.; Pisapia, P.; Pepe, F.; De Luca, C.; Migliatico, I.; Clery, E.; Greco, L.; Vigliar, E.; et al. KRAS mutations testing in non-small cell lung cancer: The role of Liquid biopsy in the basal setting. J. Thorac. Dis. 2020, 12, 3836-3843. [CrossRef]

198. Bauml, J.; Levy, B. Clonal Hematopoiesis: A New Layer in the Liquid Biopsy Story in Lung Cancer. Clin. Cancer Res. 2018, 24, 4352-4354. [CrossRef] [PubMed]

199. Chan, H.T.; Nagayama, S.; Chin, Y.M.; Otaki, M.; Hayashi, R.; Kiyotani, K.; Fukunaga, Y.; Ueno, M.; Nakamura, Y.; Low, S. Clinical significance of clonal hematopoiesis in the interpretation of blood liquid biopsy. Mol. Oncol. 2020, 14, 1719-1730. [CrossRef] [PubMed]

200. Hu, Y.; Ulrich, B.C.; Supplee, J.; Kuang, Y.; Lizotte, P.H.; Feeney, N.B.; Guibert, N.M.; Awad, M.M.; Wong, K.K.; Jänne, P.A.; et al. False-Positive Plasma Genotyping Due to Clonal Hematopoiesis. Clin. Cancer Res. 2018, 24, 4437-4443. [CrossRef] [PubMed]

201. Shlush, L.I. Age-related clonal hematopoiesis. Blood 2018, 131, 496-504. [CrossRef]

202. Holmes, M.; Mahar, A.; Lum, T.; Kao, S.; Cooper, W.A. Real-world programmed death-ligand 1 prevalence rates in non-small cell lung cancer: Correlation with clinicopathological features and tumour mutation status. J. Clin. Pathol. 2021, 74, 123-128. [CrossRef] [PubMed]

203. Jeanson, A.; Tomasini, P.; Souquet-Bressand, M.; Brandone, N.; Boucekine, M.; Grangeon, M.; Chaleat, S.; Khobta, N.; Milia, J.; Mhanna, L.; et al. Efficacy of Immune Checkpoint Inhibitors in KRAS-Mutant Non-Small Cell Lung Cancer (NSCLC). J. Thorac. Oncol. 2019, 14, 1095-1101. [CrossRef]

204. Lamberti, G.; Spurr, L.F.; Li, Y.; Ricciuti, B.; Recondo, G.; Umeton, R.; Nishino, M.; Sholl, L.M.; Meyerson, M.L.; Cherniack, A.D.; et al. Clinicopathological and genomic correlates of programmed cell death ligand 1 (PD-L1) expression in nonsquamous non-small-cell lung cancer. Ann. Oncol. 2020, 31, 807-814. [CrossRef]

205. Adderley, H.; Blackhall, F.H.; Lindsay, C.R. KRAS-mutant non-small cell lung cancer: Converging small molecules and immune checkpoint inhibition. EBioMedicine 2019, 41, 711-716. [CrossRef] [PubMed]

206. Liu, Y.; Gao, G.F.; Minna, J.D.; Williams, N.S.; Westover, K.D. Loss of wild type KRAS in KRAS lung adenocarcinoma is associated with cancer mortality and confers sensitivity to FASN inhibitors. Lung Cancer 2021, 153, 73-80. [CrossRef] [PubMed]

207. Molina-Arcas, M.; Moore, C.; Rana, S.; van Maldegem, F.; Mugarza, E.; Romero-Clavijo, P.; Herbert, E.; Horswell, S.; Li, L.-S.; Janes, M.R.; et al. Development of combination therapies to maximize the impact of KRAS-G12C inhibitors in lung cancer. Sci. Transl. Med. 2019, 11, 7999. [CrossRef]

208. Xia, M.; Li, X.; Diao, Y.; Du, B.; Li, Y. Targeted inhibition of glutamine metabolism enhances the antitumor effect of selumetinib in KRAS-mutant NSCLC. Transl. Oncol. 2021, 14, 100920. [CrossRef] [PubMed]

209. Amanam, I.; Mambetsariev, I.; Gupta, R.; Achuthan, S.; Wang, Y.; Pharaon, R.; Massarelli, E.; Koczywas, M.; Reckamp, K.; Salgia, R. Role of immunotherapy and co-mutations on KRAS-mutant non- small cell lung cancer survival. J. Thorac. Dis. 2020, 12, 5086-5095. [CrossRef]

210. Arbour, K.C.; Jordan, E.; Kim, H.R.; Dienstag, J.; Yu, H.A.; Sanchez-Vega, F.; Lito, P.; Berger, M.; Solit, D.B.; Hellmann, M.; et al. Effects of Co-occurring Genomic Alterations on Outcomes in Patients with KRAS-Mutant Non-Small Cell Lung Cancer. Clin. Cancer Res. 2018, 24, 334-340. [CrossRef]

211. Aredo, J.V.; Padda, S.K.; Kunder, C.A.; Han, S.S.; Neal, J.W.; Shrager, J.B.; Wakelee, H.A. Impact of KRAS mutation subtype and concurrent pathogenic mutations on non-small cell lung cancer outcomes. Lung Cancer 2019, 133, 144-150. [CrossRef] [PubMed]

212. Bange, E.; Marmarelis, M.E.; Hwang, W.-T.; Yang, Y.-X.; Thompson, J.C.; Rosenbaum, J.; Bauml, J.M.; Ciunci, C.; Alley, E.W.; Cohen, R.B.; et al. Impact of KRAS and TP53 Co-Mutations on Outcomes After First-Line Systemic Therapy Among Patients With STK11-Mutated Advanced Non-Small-Cell Lung Cancer. JCO Precis. Oncol. 2019, 3, 1-11. [CrossRef]

213. Biton, J.; Mansuet-Lupo, A.; Pécuchet, N.; Alifano, M.; Ouakrim, H.; Arrondeau, J.; Boudou-Rouquette, P.; Goldwasser, F.; Leroy, K.; Goc, J.; et al. TP53, STK11, and EGFR Mutations Predict Tumor Immune Profile and the Response to Anti-PD-1 in Lung Adenocarcinoma. Clin. Cancer Res. 2018, 24, 5710-5723. [CrossRef]

214. Cai, D.; Hu, C.; Li, L.; Deng, S.; Yang, J.; Han-Zhang, H.; Li, M. The prevalence and prognostic value of KRAS co-mutation subtypes in Chinese advanced non-small cell lung cancer patients. Cancer Med. 2019, 9, 84-93. [CrossRef]

215. La Fleur, L.; Falk-Sörqvist, E.; Smeds, P.; Berglund, A.; Sundström, M.; Mattsson, J.S.; Brandén, E.; Koyi, H.; Isaksson, J.; Brunnström, H.; et al. Mutation patterns in a population-based non-small cell lung cancer cohort and prognostic impact of concomitant mutations in KRAS and TP53 or STK. Lung Cancer 2019, 130, 50-58. [CrossRef]

216. Skoulidis, F.; Byers, L.A.; Diao, L.; Papadimitrakopoulou, V.A.; Tong, P.; Izzo, J.G.; Behrens, C.; Kadara, H.; Parra, E.R.; Canales, J.R.; et al. Co-occurring Genomic Alterations Define Major Subsets of KRAS-Mutant Lung Adenocarcinoma with Distinct Biology, Immune Profiles, and Therapeutic Vulnerabilities. Cancer Discov. 2015, 5, 860-877. [CrossRef] [PubMed]

217. Scheffler, M.; Ihle, M.A.; Hein, R.; Merkelbach-Bruse, S.; Scheel, A.H.; Siemanowski, J.; Brägelmann, J.; Kron, A.; Abedpour, N.; Ueckeroth, F.; et al. K-ras Mutation Subtypes in NSCLC and Associated Co-occuring Mutations in Other Oncogenic Pathways. J. Thorac. Oncol. 2019, 14, 606-616. [CrossRef] [PubMed] 
218. Skoulidis, F.; Heymach, J.V. Co-occurring genomic alterations in non-small-cell lung cancer biology and therapy. Nat. Rev. Cancer 2019, 19, 495-509. [CrossRef]

219. Skoulidis, F.; Goldberg, M.E.; Greenawalt, D.M.; Hellmann, M.D.; Awad, M.M.; Gainor, J.F.; Schrock, A.B.; Hartmaier, R.J.; Trabucco, S.E.; Gay, L.; et al. STK11/LKB1 Mutations and PD-1 Inhibitor Resistance in KRAS-Mutant Lung Adenocarcinoma. Cancer Discov. 2018, 8, 822-835. [CrossRef] [PubMed]

220. Gibert, J.; Clavé, S.; Hardy-Werbin, M.; Taus, Á.; Rocha, P.; Longarón, R.; Piquer, G.; Chaib, I.; Carcereny, E.; Morán, T.; et al. Concomitant genomic alterations in KRAS mutant advanced lung adenocarcinoma. Lung Cancer 2020, 140, 42-45. [CrossRef]

221. Domingues, I.; Cedres, S.; Callejo, A.; Vivancos, A.; Martinez-Marti, A.; Felip, E. Long duration of immunotherapy in a STK11 mutated/KRAS wild-type non-small cell lung cancer patient. Pulmonology 2020, 26, 49-50. [CrossRef] [PubMed]

222. Nadal, E.; Heeke, S.; Benzaquen, J.; Vilariño, N.; Navarro, A.; Azuara, D.; Varela, M.; Otto, J.; Baixeras, N.; Shahbazian, D.; et al. Two Patients With Advanced-Stage Lung Adenocarcinoma With Radiologic Complete Response to Nivolumab Treatment Harboring an STK11/LKB1 Mutation. JCO Precis. Oncol. 2020, 4, 1239-1245. [CrossRef]

223. Adachi, Y.; Ito, K.; Hayashi, Y.; Kimura, R.; Tan, T.Z.; Yamaguchi, R.; Ebi, H. Epithelial-to-Mesenchymal Transition is a Cause of Both Intrinsic and Acquired Resistance to KRAS G12C Inhibitor in KRAS G12C-Mutant Non-Small Cell Lung Cancer. Clin. Cancer Res. 2020, 26, 5962-5973. [CrossRef]

224. Cannataro, V.L.; Gaffney, S.G.; Stender, C.; Zhao, Z.-M.; Philips, M.; Greenstein, A.E.; Townsend, J.P. Heterogeneity and mutation in KRAS and associated oncogenes: Evaluating the potential for the evolution of resistance to targeting of KRAS G12C. Oncogene 2018, 37, 2444-2455. [CrossRef] [PubMed]

225. Dunnett-Kane, V.; Nicola, P.; Blackhall, F.; Lindsay, C. Mechanisms of Resistance to KRAS ${ }^{\text {G12C }}$ Inhibitors. Cancers 2021, $13,151$. [CrossRef]

226. Hata, A.N.; Shaw, A.T. Resistance looms for KRASG12C inhibitors. Nat. Med. 2020, 26, 169-170. [CrossRef] [PubMed]

227. Yaeger, R.; Solit, D.B. Overcoming Adaptive Resistance to KRAS Inhibitors Through Vertical Pathway Targeting. Clin. Cancer Res. 2020, 26, 1538-1540. [CrossRef]

228. Mehta, A.; Nathany, S.; Tripathi, R.; Sharma, S.K.; Saifi, M.; Batra, U. Non-amplification genetic alterations ofHER2gene in non-small cell lung carcinoma. J. Clin. Pathol. 2021, 74, 106-110. [CrossRef] [PubMed]

229. Landi, L.; Cappuzzo, F. HER2 and lung cancer. Expert Rev. Anticancer. Ther. 2013, 13, 1219-1228. [CrossRef] [PubMed]

230. Mazières, J.; Peters, S.; Lepage, B.; Cortot, A.; Barlesi, F.; Beau-Faller, M.; Besse, B.; Blons, H.; Mansuet-Lupo, A.; Urban, T.; et al. Lung Cancer That Harbors an HER2 Mutation: Epidemiologic Characteristics and Therapeutic Perspectives. J. Clin. Oncol. 2013, 31, 1997-2003. [CrossRef]

231. Fois, S.S.; Paliogiannis, P.; Zinellu, A.; Fois, A.G.; Cossu, A.; Palmieri, G. Molecular Epidemiology of the Main Druggable Genetic Alterations in Non-Small Cell Lung Cancer. Int. J. Mol. Sci. 2021, 22, 612. [CrossRef]

232. Xu, F.; Yang, G.; Xu, H.; Yang, L.; Qiu, W.; Wang, Y. Treatment outcome and clinical characteristics of HER2 mutated advanced non-small cell lung cancer patients in China. Thorac. Cancer 2020, 11, 679-685. [CrossRef]

233. Offin, M.; Feldman, D.; Ni, A.; Myers, M.L.; Lai, W.V.; Pentsova, E.; Boire, A.; Daras, M.; Jordan, E.J.; Solit, D.B.; et al. Frequency and outcomes of brain metastases in patients with HER2 -mutant lung cancers. Cancer 2019, 125, 4380-4387. [CrossRef]

234. Baraibar, I.; Mezquita, L.; Gil-Bazo, I.; Planchard, D. Novel drugs targeting EGFR and HER2 exon 20 mutations in metastatic NSCLC. Crit. Rev. Oncol. 2020, 148, 102906. [CrossRef]

235. Del Re, M.; Cucchiara, F.; Petrini, I.; Fogli, S.; Passaro, A.; Crucitta, S.; Attili, I.; De Marinis, F.; Chella, A.; Danesi, R. erbB in NSCLC as a molecular target: Current evidences and future directions. ESMO Open 2020, 5, 724. [CrossRef]

236. Ekman, S. HER2: Defining a Neu target in non-small-cell lung cancer. Ann. Oncol. 2019, 30, 353-355. [CrossRef]

237. Horvath, L.; Pircher, A. ASCO 2020 non-small lung cancer (NSCLC) personal highlights. Memo. Mag. Eur. Med. Oncol. 2021, 14, 66-69. [CrossRef]

238. Koga, T.; Kobayashi, Y.; Tomizawa, K.; Suda, K.; Kosaka, T.; Sesumi, Y.; Fujino, T.; Nishino, M.; Ohara, S.; Chiba, M.; et al. Activity of a novel HER2 inhibitor, poziotinib, for HER2 exon 20 mutations in lung cancer and mechanism of acquired resistance: An in vitro study. Lung Cancer 2018, 126, 72-79. [CrossRef]

239. Liu, S.; Li, S.; Hai, J.; Wang, X.; Chen, T.; Quinn, M.M.; Gao, P.; Zhang, Y.; Ji, H.; Cross, D.A.; et al. Targeting HER2 Aberrations in Non-Small Cell Lung Cancer with Osimertinib. Clin. Cancer Res. 2018, 24, 2594-2604. [CrossRef]

240. Oh, D.-Y.; Bang, Y.-J. HER2-targeted therapies-a role beyond breast cancer. Nat. Rev. Clin. Oncol. 2020, 17, 33-48. [CrossRef]

241. Patil, T.; Mushtaq, R.; Marsh, S.; Azelby, C.; Pujara, M.; Davies, K.D.; Aisner, D.L.; Purcell, W.T.; Schenk, E.L.; Pacheco, J.M.; et al. Clinicopathologic Characteristics, Treatment Outcomes, and Acquired Resistance Patterns of Atypical EGFR Mutations and HER2 Alterations in Stage IV Non-Small-Cell Lung Cancer. Clin. Lung Cancer 2020, 21, 191-204. [CrossRef]

242. Pillai, R.N.; Behera, M.; Berry, L.D.; Rossi, M.R.; Kris, M.G.; Johnson, B.E.; Bunn, P.A.; Ramalingam, S.S.; Khuri, F.R. HER2 mutations in lung adenocarcinomas: A report from the Lung Cancer Mutation Consortium. Cancer 2017, 123, 4099-4105. [CrossRef]

243. Hotta, K.; Yanai, H.; Ohashi, K.; Ninomiya, K.; Nakashima, H.; Kayatani, H.; Takata, M.; Kiura, K. Pilot evaluation of a HER2 testing in non-small-cell lung cancer. J. Clin. Pathol. 2019, 73, 353-357. [CrossRef] [PubMed]

244. Li, B.T.; Ross, D.S.; Aisner, D.L.; Chaft, J.E.; Hsu, M.; Kako, S.L.; Kris, M.G.; Varella-Garcia, M.; Arcila, M.E. HER2 Amplification and HER2 Mutation Are Distinct Molecular Targets in Lung Cancers. J. Thorac. Oncol. 2016, 11, 414-419. [CrossRef] 
245. Cadranel, J.; Liu, S.V.; Duruisseaux, M.; Branden, E.; Goto, Y.; Weinberg, B.A.; Heining, C.; Schlenk, R.F.; Cheema, P.; Jones, M.R.; et al. Therapeutic Potential of Afatinib in NRG1 Fusion-Driven Solid Tumors: A Case Series. Oncologist 2021, 26, 7-16. [CrossRef]

246. Fernandez-Cuesta, L.; Thomas, R.K. Molecular Pathways: Targeting NRG1 Fusions in Lung Cancer. Clin. Cancer Res. 2015, 21, 1989-1994. [CrossRef] [PubMed]

247. Laskin, J.; Liu, S.; Tolba, K.; Heining, C.; Schlenk, R.; Cheema, P.; Cadranel, J.; Jones, M.; Drilon, A.; Cseh, A.; et al. NRG1 fusion-driven tumors: Biology, detection, and the therapeutic role of afatinib and other ErbB-targeting agents. Ann. Oncol. 2020, 31, 1693-1703. [CrossRef] [PubMed]

248. Drilon, A.; Somwar, R.; Mangatt, B.P.; Edgren, H.; Desmeules, P.; Ruusulehto, A.; Smith, R.S.; Delasos, L.; Vojnic, M.; Plodkowski, A.J.; et al. Response to ERBB3-Directed Targeted Therapy in NRG1-Rearranged Cancers. Cancer Discov. 2018, 8, 686-695. [CrossRef]

249. Duruisseaux, M.; McLeer-Florin, A.; Antoine, M.; Alavizadeh, S.; Poulot, V.; Lacave, R.; Rabbe, N.; Cadranel, J.; Wislez, M. NRG1 fusion in a French cohort of invasive mucinous lung adenocarcinoma. Cancer Med. 2016, 5, 3579-3585. [CrossRef]

250. Agaimy, A.; Fuchs, F.; Moskalev, E.A.; Sirbu, H.; Hartmann, A.; Haller, F. SMARCA4-deficient pulmonary adenocarcinoma: Clinicopathological, immunohistochemical, and molecular characteristics of a novel aggressive neoplasm with a consistent TTF1neg/CK7pos/HepPar-1pos immunophenotype. Virchows Arch. 2017, 471, 599-609. [CrossRef] [PubMed]

251. Agaimy, A.; Daum, O.; Michal, M.; Schmidt, M.W.; Stoehr, R.; Hartmann, A.; Lauwers, G.Y. Undifferentiated large cell/rhabdoid carcinoma presenting in the intestines of patients with concurrent or recent non-small cell lung cancer (NSCLC): Clinicopathologic and molecular analysis of 14 cases indicates an unusual pattern of dedifferentiated metastases. Virchows Arch. 2021. [CrossRef]

252. Bell, E.H.; Chakraborty, A.R.; Mo, X.; Liu, Z.; Shilo, K.; Kirste, S.; Stegmaier, P.; McNulty, M.; Karachaliou, N.; Rosell, R.; et al. SMARCA4/BRG1 Is a Novel Prognostic Biomarker Predictive of Cisplatin-Based Chemotherapy Outcomes in Resected Non-Small Cell Lung Cancer. Clin. Cancer Res. 2016, 22, 2396-2404. [CrossRef]

253. Chatzopoulos, K.; Boland, J.M. Update on genetically defined lung neoplasms: NUT carcinoma and thoracic SMARCA4-deficient undifferentiated tumors. Virchows Arch. 2021, 478, 21-30. [CrossRef]

254. Chetty, R.; Serra, S. SMARCA family of genes. J. Clin. Pathol. 2020, 73, 257-260. [CrossRef]

255. Geng, H.; Li, S.; Guo, Y.; Yan, F.; Han, Y.; Xu, M.; Cui, Y. Survival prediction for patients with lung adenocarcinoma: A prognostic risk model based on gene mutations. Cancer Biomark. 2020, 27, 525-532. [CrossRef] [PubMed]

256. Liu, L.; Ahmed, T.; Petty, W.J.; Grant, S.; Ruiz, J.; Lycan, T.W.; Topaloglu, U.; Chou, P.; Miller, L.D.; Hawkins, G.A.; et al. SMARCA4 mutations in KRAS-mutant lung adenocarcinoma: A multi-cohort analysis. Mol. Oncol. 2021, 15, 462-472. [CrossRef]

257. Rekhtman, N.; Montecalvo, J.; Chang, J.C.; Alex, D.; Ptashkin, R.N.; Ai, N.; Sauter, J.L.; Kezlarian, B.; Jungbluth, A.; Desmeules, P.; et al. SMARCA4-Deficient Thoracic Sarcomatoid Tumors Represent Primarily Smoking-Related Undifferentiated Carcinomas Rather Than Primary Thoracic Sarcomas. J. Thorac. Oncol. 2020, 15, 231-247. [CrossRef] [PubMed]

258. Sesboue, C.; Le Loarer, F. SWI/SNF-deficient thoraco-pulmonary neoplasms. Semin. Diagn. Pathol. 2021, 38, 183-194. [CrossRef] [PubMed]

259. Dagogo-Jack, I.; Schrock, A.B.; Kem, M.; Jessop, N.; Lee, J.; Ali, S.M.; Ross, J.S.; Lennerz, J.K.; Shaw, A.T.; Mino-Kenudson, M. Clinicopathologic Characteristics of BRG1-Deficient NSCLC. J. Thorac. Oncol. 2020, 15, 766-776. [CrossRef]

260. Fernando, T.M.; Piskol, R.; Bainer, R.; Sokol, E.S.; Trabucco, S.E.; Zhang, Q.; Trinh, H.; Maund, S.; Kschonsak, M.; Chaudhuri, S.; et al. Functional characterization of SMARCA4 variants identified by targeted exome-sequencing of 131,668 cancer patients. Nat. Commun. 2020, 11, 5551. [CrossRef]

261. Schoenfeld, A.J.; Bandlamudi, C.; Lavery, J.A.; Montecalvo, J.; Namakydoust, A.; Rizvi, H.; Egger, J.V.; Concepcion, C.P.; Paul, S.; Arcila, M.E.; et al. The Genomic Landscape of SMARCA4 Alterations and Associations with Outcomes in Patients with Lung Cancer. Clin. Cancer Res. 2020, 26, 5701-5708. [CrossRef]

262. Tagal, V.; Wei, S.; Zhang, W.; Brekken, R.A.; Posner, B.A.; Peyton, M.; Girard, L.; Hwang, T.; Wheeler, D.A.; Minna, J.D.; et al. SMARCA4-inactivating mutations increase sensitivity to Aurora kinase A inhibitor VX-680 in non-small cell lung cancers. Nat. Commun. 2017, 8, 14098. [CrossRef]

263. Xue, Y.; Meehan, B.; Fu, Z.; Wang, X.Q.D.; Fiset, P.O.; Rieker, R.; Levins, C.; Kong, T.; Zhu, X.; Morin, G.; et al. SMARCA4 loss is synthetic lethal with CDK4/6 inhibition in non-small cell lung cancer. Nat. Commun. 2019, 10, 557. [CrossRef]

264. Deribe, Y.L.; Sun, Y.; Terranova, C.; Khan, F.; Martinez-Ledesma, J.; Gay, J.; Gao, G.; Mullinax, R.A.; Khor, T.; Feng, N.; et al. Mutations in the SWI/SNF complex induce a targetable dependence on oxidative phosphorylation in lung cancer. Nat. Med. 2018, 24, 1047-1057. [CrossRef]

265. Papillon, J.P.N.; Nakajima, K.; Adair, C.D.; Hempel, J.; Jouk, A.O.; Karki, R.G.; Mathieu, S.; Moebitz, H.; Ntaganda, R.; Smith, T.; et al. Discovery of Orally Active Inhibitors of Brahma Homolog (BRM)/SMARCA2 ATPase Activity for the Treatment of Brahma Related Gene 1 (BRG1)/SMARCA4-Mutant Cancers. J. Med. Chem. 2018, 61, 10155-10172. [CrossRef]

266. Yamagishi, M.; Uchimaru, K. Targeting EZH2 in cancer therapy. Curr. Opin. Oncol. 2017, 29, 375-381. [CrossRef] [PubMed]

267. Henon, C.; Blay, J.-Y.; Massard, C.; Mir, O.; Bahleda, R.; Dumont, S.; Postel-Vinay, S.; Adam, J.; Soria, J.-C.; Le Cesne, A. Long lasting major response to pembrolizumab in a thoracic malignant rhabdoid-like SMARCA4-deficient tumor. Ann. Oncol. 2019, 30, 1401-1403. [CrossRef] [PubMed]

268. Naito, T.; Umemura, S.; Nakamura, H.; Zenke, Y.; Udagawa, H.; Kirita, K.; Matsumoto, S.; Yoh, K.; Niho, S.; Motoi, N.; et al. Successful treatment with nivolumab for SMARCA4-deficient non-small cell lung carcinoma with a high tumor mutation burden: A case report. Thorac. Cancer 2019, 10, 1285-1288. [CrossRef] [PubMed] 
269. Zhou, H.; Shen, J.; Liu, J.; Fang, W.; Zhang, L. Efficacy of Immune Checkpoint Inhibitors in SMARCA4-Mutant NSCLC. J. Thorac. Oncol. 2020, 15, 133-136. [CrossRef]

270. Chiba, Y.; Kawanami, T.; Yamasaki, K.; Uchimura, K.; Matsuyama, A.; Yatera, K. Hyper-progressive disease after immune checkpoint inhibitor in SMARCA4 -deficient small-cell lung carcinoma. Respirol. Case Rep. 2020, 8, 00667. [CrossRef] [PubMed]

271. Orlando, K.A.; Nguyen, V.; Raab, J.R.; Walhart, T.; Weissman, B.E. Remodeling the cancer epigenome: Mutations in the SWI/SNF complex offer new therapeutic opportunities. Expert Rev. Anticancer. Ther. 2019, 19, 375-391. [CrossRef]

272. Early, C.A.; Wangsiricharoen, S.; Jones, R.M.; VandenBussche, C.J. Review of SMARCA4 (BRG1)-deficient carcinomas following a malignant pleural effusion specimen confounded by reduced claudin-4 expression. J. Am. Soc. Cytopathol. 2021, 10, 197-207. [CrossRef]

273. Herpel, E.; Rieker, R.J.; Dienemann, H.; Muley, T.; Meister, M.; Hartmann, A.; Warth, A.; Agaimy, A. SMARCA4 and SMARCA2 deficiency in non-small cell lung cancer: Immunohistochemical survey of 316 consecutive specimens. Ann. Diagn. Pathol. 2017, 26, 47-51. [CrossRef]

274. Nambirajan, A.; Singh, V.; Bhardwaj, N.; Mittal, S.; Kumar, S.; Jain, D. SMARCA4/BRG1-Deficient Non-Small Cell Lung Carcinomas: A Case Series and Review of the Literature. Arch. Pathol. Lab. Med. 2021, 145, 90-98. [CrossRef] [PubMed]

275. Nambirajan, A.; Dutta, R.; Malik, P.S.; Bubendorf, L.; Jain, D. Cytology of SMARCA4-Deficient Thoracic Neoplasms: Comparative Analysis of SMARCA4-Deficient Non-Small Cell Lung Carcinomas and SMARCA4-Deficient Thoracic Sarcomas. Acta Cytol. 2021, 65, 67-74. [CrossRef]

276. Cao, J.; Chen, D.; Yang, F.; Yao, J.; Zhu, W.; Zhao, C. NUT midline carcinoma as a primary lung tumor: A case report. J. Thorac. Dis. 2017, 9, 1045-1049. [CrossRef]

277. Cho, Y.A.; Choi, Y.; Hwang, I.; Lee, K.; Cho, J.H.; Han, J. Clinicopathological characteristics of primary lung nuclear protein in testis carcinoma: A single-institute experience of 10 cases. Thorac. Cancer 2020, 11, 3205-3212. [CrossRef]

278. Cho, H.J.; Lee, H. Lung nuclear protein in testis carcinoma in an elderly Korean woman: A case report with cytohistological analysis. Thorac. Cancer 2020, 11, 1724-1727. [CrossRef] [PubMed]

279. Harms, A.; Herpel, E.; Pfarr, N.; Penzel, R.; Heussel, C.-P.; Herth, F.J.; Dienemann, H.; Weichert, W.; Warth, A. NUT carcinoma of the thorax: Case report and review of the literature. Lung Cancer 2015, 90, 484-491. [CrossRef]

280. Karakuş, E.; Poyraz, A.; Erdogan, A.S.O.; Emir, S.; Özyörük, D. NUT midline carcinoma of the lung in a six-year-old child. Fetal Pediatr. Pathol. 2017, 36, 472-474. [CrossRef]

281. Lund-Iversen, M.; Grøholt, K.K.; Helland, Å.; Borgen, E.; Brustugun, O.T. NUT expression in primary lung tumours. Diagn. Pathol. 2015, 10, 156. [CrossRef]

282. Sholl, L.M.; Nishino, M.; Pokharel, S.; Mino-Kenudson, M.; French, C.A.; Janne, P.A.; Lathan, C. Primary Pulmonary NUT Midline Carcinoma: Clinical, Radiographic, and Pathologic Characterizations. J. Thorac. Oncol. 2015, 10, 951-959. [CrossRef] [PubMed]

283. French, C.A. NUT Carcinoma: Clinicopathologic features, pathogenesis, and treatment. Pathol. Int. 2018, 68, 583-595. [CrossRef]

284. Hakun, M.; Gu, B. Challenges and Opportunities in NUT Carcinoma Research. Genes 2021, 12, 235. [CrossRef] [PubMed]

285. Matsubara, D.; Kishaba, Y.; Ishikawa, S.; Sakatani, T.; Oguni, S.; Tamura, T.; Hoshino, H.; Sugiyama, Y.; Endo, S.; Murakami, Y.; et al. Lung cancer with loss of BRG1/BRM, shows epithelial mesenchymal transition phenotype and distinct histologic and genetic features. Cancer Sci. 2013, 104, 266-273. [CrossRef] [PubMed]

286. Fujioka, N.; French, C.A.; Cameron, M.J.; Kratzke, R.A. Long-Term Survival of a Patient with Squamous Cell Carcinoma Harboring NUT Gene Rearrangement. J. Thorac. Oncol. 2010, 5, 1704-1705. [CrossRef] [PubMed]

287. Baras, A.S.; Naidoo, J.; Hann, C.L.; Illei, P.B.; Iii, C.W.R.; Lauring, J. Rediagnosis of Lung Cancer as NUT Midline Carcinoma Based on Clues From Tumor Genomic Profiling. J. Natl. Compr. Cancer Netw. 2018, 16, 467-472. [CrossRef]

288. Chau, N.G.; Ma, C.; Danga, K.; Al-Sayegh, H.; Nardi, V.; Barrette, R.; Lathan, C.S.; Dubois, S.G.; Haddad, R.I.; Shapiro, G.I.; et al. An Anatomical Site and Genetic-Based Prognostic Model for Patients With Nuclear Protein in Testis (NUT) Midline Carcinoma: Analysis of 124 Patients. JNCI Cancer Spectr. 2019, 4, 94. [CrossRef]

289. Parikh, S.A.; French, C.A.; Costello, B.A.; Marks, R.S.; Dronca, R.S.; Nerby, C.L.; Roden, A.C.; Peddareddigari, V.G.; Hilton, J.; Shapiro, G.I.; et al. NUT Midline Carcinoma: An Aggressive Intrathoracic Neoplasm. J. Thorac. Oncol. 2013, 8, 1335-1338. [CrossRef]

290. Suzuki, S.; Kurabe, N.; Ohnishi, I.; Yasuda, K.; Aoshima, Y.; Naito, M.; Tanioka, F.; Sugimura, H. NSD3-NUT-expressing midline carcinoma of the lung: First characterization of primary cancer tissue. Pathol. Res. Pract. 2015, 211, 404-408. [CrossRef]

291. Tanaka, M.; Kato, K.; Gomi, K.; Yoshida, M.; Niwa, T.; Aida, N.; Kigasawa, H.; Ohama, Y.; Tanaka, Y. NUT Midline Carcinoma. Am. J. Surg. Pathol. 2012, 36, 381-388. [CrossRef] [PubMed]

292. Haack, H.; Johnson, L.A.; Fry, C.J.; Crosby, K.; Polakiewicz, R.D.; Stelow, E.B.; Hong, S.-M.; Schwartz, B.E.; Cameron, M.J.; Rubin, M.A.; et al. Diagnosis of NUT Midline Carcinoma Using a NUT-specific Monoclonal Antibody. Am. J. Surg. Pathol. 2009, 33, 984-991. [CrossRef]

293. Inamura, K. Update on Immunohistochemistry for the Diagnosis of Lung Cancer. Cancers 2018, 10, 72. [CrossRef]

294. Kuroda, S.; Suzuki, S.; Kurita, A.; Muraki, M.; Aoshima, Y.; Tanioka, F.; Sugimura, H. Cytological Features of a Variant NUT Midline Carcinoma of the Lung Harboring theNSD3-NUTFusion Gene: A Case Report and Literature Review. Case Rep. Pathol. 2015, 2015, 572951. [CrossRef]

295. Lee, J.-K.; Louzada, S.; An, Y.; Kim, S.Y.; Youk, J.; Park, S.; Koo, S.H.; Keam, B.; Jeon, Y.K.; Ku, J.-L.; et al. Complex chromosomal rearrangements by single catastrophic pathogenesis in NUT midline carcinoma. Ann. Oncol. 2017, 28, 890-897. [CrossRef] 
296. Mack, P.C.; Ms, K.C.B.; Ms, C.R.E.; Ms, R.A.B.; Zill, O.A.; Ms, C.E.L.; Riess, J.W.; Mortimer, S.A.; Talasaz, A.; Lanman, R.B.; et al. Spectrum of driver mutations and clinical impact of circulating tumor DNA analysis in non-small cell lung cancer: Analysis of over 8000 cases. Cancer 2020, 126, 3219-3228. [CrossRef]

297. Policarpio-Nicolas, M.L.C.; de Leon, E.M.B.; Jagirdar, J. Cytologic findings of NUT midline carcinoma in the hilum of the lung. Diagn. Cytopathol. 2015, 43, 739-742. [CrossRef]

298. Bishop, J.A.; French, C.A.; Ali, S.Z. Cytopathologic features of NUT midline carcinoma: A series of 26 specimens from 13 patients. Cancer Cytopathol. 2016, 124, 901-908. [CrossRef]

299. Dutta, R.; Nambirajan, A.; Mittal, S.; Roy-Chowdhuri, S.; Jain, D. Cytomorphology of primary pulmonary NUT carcinoma in different cytology preparations. Cancer Cytopathol. 2021, 129, 53-61. [CrossRef] [PubMed]

300. Matsuda, K.; Kashima, J.; Yatabe, Y. The Isoform Matters in NUT Carcinoma: A Diagnostic Pitfall of p40 Immunohistochemistry. J. Thorac. Oncol. 2020, 15, 176-178. [CrossRef] [PubMed]

301. Hung, Y.P.; Chen, A.L.; Taylor, M.S.; Huynh, T.G.; Kem, M.; Selig, M.K.; Nielsen, G.P.; Lennerz, J.K.; Azzoli, C.G.; Dagogo-Jack, I.; et al. Thoracic nuclear protein in testis (NUT) carcinoma: Expanded pathological spectrum with expression of thyroid transcription factor-1 and neuroendocrine markers. Histopathology 2021, 78, 896-904. [CrossRef]

302. Numakura, S.; Saito, K.; Motoi, N.; Mori, T.; Saito, Y.; Yokote, F.; Kanamoto, Y.; Asami, M.; Sakai, T.; Yamauchi, Y.; et al. P63-negative pulmonary NUT carcinoma arising in the elderly: A case report. Diagn. Pathol. 2020, 15, 134. [CrossRef]

303. Pezzuto, F.; Fortarezza, F.; Mammana, M.; Pasello, G.; Pelosi, G.; Rea, F.; Calabrese, F. Immunohistochemical neuroendocrine marker expression in primary pulmonary NUT carcinoma: A diagnostic pitfall. Histopathology 2020, 77, 508-510. [CrossRef] [PubMed]

304. Mbbs, K.D.S.; Stanzione, N.; Caron, J.E.; Fishbein, G.A.; Abtin, F.; Lluri, G.; Hirschowitz, S.L. Midline carcinoma expressing NUT in malignant effusion cytology. Diagn. Cytopathol. 2019, 47, 594-598. [CrossRef]

305. Eagen, K.P.; French, C.A. Supercharging BRD4 with NUT in carcinoma. Oncogene 2021, 40, 1396-1408. [CrossRef]

306. Sahai, V.; Redig, A.J.; Collier, K.A.; Eckerdt, F.D.; Munshi, H.G. Targeting BET bromodomain proteins in solid tumors. Oncotarget 2016, 7, 53997-54009. [CrossRef] [PubMed]

307. Stathis, A.; Bertoni, F. BET Proteins as Targets for Anticancer Treatment. Cancer Discov. 2017, 8, 24-36. [CrossRef] [PubMed]

308. Davis, A.; Mahar, A.; Wong, K.; Barnett, M.; Kao, S. Prolonged Disease Control on Nivolumab for Primary Pulmonary NUT Carcinoma. Clin. Lung Cancer 2020. [CrossRef] [PubMed]

309. Morrison-Smith, C.D.; Knox, T.M.; Filic, I.; Soroko, K.M.; Eschle, B.K.; Wilkens, M.K.; Gokhale, P.C.; Giles, F.; Griffin, A.; Brown, B.; et al. Combined Targeting of the BRD4-NUT-p300 Axis in NUT Midline Carcinoma by Dual Selective Bromodomain Inhibitor, NEO2734. Mol. Cancer Ther. 2020, 19, 1406-1414. [CrossRef] [PubMed]

310. Lewin, J.; Soria, J.-C.; Stathis, A.; Delord, J.-P.; Peters, S.; Awada, A.; Aftimos, P.G.; Bekradda, M.; Rezai, K.; Zeng, Z.; et al. Phase Ib Trial With Birabresib, a Small-Molecule Inhibitor of Bromodomain and Extraterminal Proteins, in Patients With Selected Advanced Solid Tumors. J. Clin. Oncol. 2018, 36, 3007-3014. [CrossRef]

311. Zhang, X.; Zegar, T.; Lucas, A.; Morrison-Smith, C.; Knox, T.; French, C.A.; Knapp, S.; Müller, S.; Siveke, J.T. Therapeutic targeting of p300/CBP HAT domain for the treatment of NUT midline carcinoma. Oncogene 2020, 39, 4770-4779. [CrossRef]

312. Mograbi, B.; Heeke, S.; Hofman, P. The Importance of STK11/LKB1 Assessment in Non-Small Cell Lung Carcinomas. Diagnostics 2021, 11, 196. [CrossRef] [PubMed]

313. Hasegawa, T.; Yanagitani, N.; Ninomiya, H.; Sakamoto, H.; Tozuka, T.; Yoshida, H.; Amino, Y.; Uematsu, S.; Yoshizawa, T.; Ariyasu, R.; et al. Association Between the Efficacy of Pembrolizumab and Low STK11/LKB1 Expression in High-PD-L1-expressing Non-small-cell Lung Cancer. In Vivo 2020, 34, 2997-3003. [CrossRef]

314. Kwack, W.G.; Shin, S.Y.; Lee, S.H. Primary Resistance to Immune Checkpoint Blockade in an STK11/TP53/KRAS-Mutant Lung Adenocarcinoma with High PD-L1 Expression. Onco. Targets Ther. 2020, 13, 8901-8905. [CrossRef]

315. Laderian, B.; Mundi, P.; Fojo, T.; Bates, S.E. Emerging Therapeutic Implications of STK11 Mutation: Case Series. Oncologist 2020, 25, 733-737. [CrossRef]

316. Arauz, R.F.; Byun, J.S.; Tandon, M.; Sinha, S.; Kuhn, S.; Taylor, S.; Zingone, A.; Mitchell, K.A.; Pine, S.R.; Gardner, K.; et al. Whole-Exome Profiling of NSCLC Among African Americans. J. Thorac. Oncol. 2020, 15, 1880-1892. [CrossRef]

317. Shen, H.; Zhu, M.; Wang, C. Precision oncology of lung cancer: Genetic and genomic differences in Chinese population. NPJ Precis. Oncol. 2019, 3, 14. [CrossRef]

318. Adachi, Y.; Watanabe, K.; Kita, K.; Kitai, H.; Kotani, H.; Sato, Y.; Inase, N.; Yano, S.; Ebi, H. Resistance mediated by alternative receptor tyrosine kinases in FGFR1-amplified lung cancer. Carcinogenesis 2017, 38, 1063-1072. [CrossRef]

319. Desai, A.; Adjei, A.A. FGFR Signaling as a Target for Lung Cancer Therapy. J. Thorac. Oncol. 2016, 11, 9-20. [CrossRef] [PubMed]

320. Hegab, A.E.; Ozaki, M.; Kameyama, N.; Gao, J.; Kagawa, S.; Yasuda, H.; Soejima, K.; Yin, Y.; Guzy, R.D.; Nakamura, Y.; et al. Effect of FGF/FGFR pathway blocking on lung adenocarcinoma and its cancer-associated fibroblasts. J. Pathol. 2019, 249, 193-205. [CrossRef] [PubMed]

321. Touat, M.; Ileana, E.; Postel-Vinay, S.; André, F.; Soria, J.-C. Targeting FGFR Signaling in Cancer. Clin. Cancer Res. 2015, 21, 2684-2694. [CrossRef]

322. Weeden, C.; Solomon, B.; Asselin-Labat, M.-L. FGFR1 inhibition in lung squamous cell carcinoma: Questions and controversies. Cell Death Discov. 2015, 1, 15049. [CrossRef] 
323. Cheng, M.L.; Pectasides, E.; Hanna, G.J.; Parsons, H.A.; Choudhury, A.D.; Oxnard, G.R. Circulating tumor DNA in advanced solid tumors: Clinical relevance and future directions. CA A Cancer J. Clin. 2021, 71, 176-190. [CrossRef]

324. Hofman, V.; Heeke, S.; Allegra, M.; Ilie, M.; Hofman, P. Liquid biopsy and genomic assessement for lung cancer: The role in clinical practice. In Oncogenomics: From Basic Research to Precision Medicine; Franco, D., Franco, S., Eds.; Elsevier: Amsterdam, The Netherlands, 2019; Volume 11, pp. 165-180.

325. Roncarati, R.; Lupini, L.; Miotto, E.; Saccenti, E.; Mascetti, S.; Morandi, L.; Bassi, C.; Rasio, D.; Callegari, E.; Conti, V.; et al. Molecular testing on bronchial washings for the diagnosis and predictive assessment of lung cancer. Mol. Oncol. 2020, 14, 2163-2175. [CrossRef] [PubMed]

326. Satoh, Y.; Matsuo, Y.; Kuba, T.; Yamashita, K.; Sawano, M.; Tozaka, S.; Yamazaki, H.; Sonoda, D.; Mikubo, M.; Naito, M.; et al. EGFR mutation genotyping and ALK status determination in liquid-based cytology samples of non-small cell lung cancer. Virchows Arch. 2019, 476, 753-762. [CrossRef] [PubMed]

327. Wang, X.; Chen, S.; Emerson, R.E.; Wu, H.H.; Cramer, H.M.; Curless, K.; Chang, H.Y.; Zhang, S.; Randolph, M.L.; Cheng, L. Molecular Testing for EGFR Mutations and ALK Rearrangements in the Cytological Specimens From the Patients With Non-Small Cell Lung Cancer. Appl. Immunohistochem. Mol. Morphol. 2019, 27, 119-124. [CrossRef] [PubMed]

328. Kilgour, E.; Rothwell, D.G.; Brady, G.; Dive, C. Liquid Biopsy-Based Biomarkers of Treatment Response and Resistance. Cancer Cell 2020, 37, 485-495. [CrossRef] [PubMed]

329. Krishnamurthy, N.; Spencer, E.; Torkamani, A.; Nicholson, L. Liquid Biopsies for Cancer: Coming to a Patient near You. J. Clin. Med. 2017, 6, 3. [CrossRef] [PubMed]

330. Makarem, M.; Leighl, N.B. Molecular testing for lung adenocarcinoma: Is it time to adopt a "plasma-first" approach? Cancer 2020, 126, 3176-3180. [CrossRef]

331. Aldea, M.; Hendriks, L.; Mezquita, L.; Jovelet, C.; Planchard, D.; Auclin, E.; Remon, J.; Howarth, K.; Benitez, J.C.; Gazzah, A.; et al. Circulating Tumor DNA Analysis for Patients with Oncogene-Addicted NSCLC With Isolated Central Nervous System Progression. J. Thorac. Oncol. 2020, 15, 383-391. [CrossRef]

332. Dagogo-Jack, I.; Shaw, A.T. Tumour heterogeneity and resistance to cancer therapies. Nat. Rev. Clin. Oncol. 2018, 15, 81-94. [CrossRef]

333. Bonanno, L.; Pavan, A.; Ferro, A.; Calvetti, L.; Frega, S.; Pasello, G.; Aprile, G.; Guarneri, V.; Conte, P.; Rete Oncologica Veneta (ROV). Clinical Impact of Plasma and Tissue Next-Generation Sequencing in Advanced Non-Small Cell Lung Cancer: A Real-World Experience. Oncologis 2020, 25, 1996-2005. [CrossRef]

334. Heeke, S.; Hofman, P. Tumor mutational burden assessment as a predictive biomarker for immunotherapy in lung cancer patients: Getting ready for prime-time or not? Transl. Lung Cancer Res. 2018, 7, 631-638. [CrossRef]

335. Aggarwal, C.; Thompson, J.C.; Chien, A.L.; Quinn, K.J.; Hwang, W.-T.; Black, T.A.; Yee, S.S.; Christensen, T.E.; Lariviere, M.J.; Silva, B.A.; et al. Baseline Plasma Tumor Mutation Burden Predicts Response to Pembrolizumab-based Therapy in Patients with Metastatic Non-Small Cell Lung Cancer. Clin. Cancer Res. 2020, 26, 2354-2361. [CrossRef]

336. Gandara, D.R.; Paul, S.M.; Kowanetz, M.; Schleifman, E.; Zou, W.; Li, Y.; Rittmeyer, A.; Fehrenbacher, L.; Otto, G.; Malboeuf, C.; et al. Blood-based tumor mutational burden as a predictor of clinical benefit in non-small-cell lung cancer patients treated with atezolizumab. Nat. Med. 2018, 24, 1441-1448. [CrossRef] [PubMed]

337. Si, H.; Kuziora, M.; Quinn, K.J.; Helman, E.; Ye, J.; Liu, F.; Scheuring, U.; Peters, S.; Rizvi, N.A.; Brohawn, P.Z.; et al. A Blood-based Assay for Assessment of Tumor Mutational Burden in First-line Metastatic NSCLC Treatment: Results from the MYSTIC Study. Clin. Cancer Res. 2021, 27, 1631-1640. [CrossRef] [PubMed]

338. Pepe, F.; Pisapia, P.; Gristina, V.; Rocco, D.; Bs, M.M.; Micheli, P.; Iaccarino, A.; Tufano, R.; Bs, G.G.; De Luca, C.; et al. Tumor mutational burden on cytological samples: A pilot study. Cancer Cytopathol. 2020. [CrossRef]

339. Berland, L.; Heeke, S.; Humbert, O.; Macocco, A.; Long-Mira, E.; Lassalle, S.; Lespinet-Fabre, V.; Lalvée, S.; Bordone, O.; Cohen, C.; et al. Current views on tumor mutational burden in patients with non-small cell lung cancer treated by immune checkpoint inhibitors. J. Thorac. Dis. 2019, 11, 71-80. [CrossRef] [PubMed]

340. Gyawali, B.; West, H.J. Plasma vs Tissue Next-Generation Sequencing in Non-Small Cell Lung Cancer-Either, Both, or Neither? JAMA Oncol. 2019, 5, 148. [CrossRef]

341. Ignatiadis, M.; Sledge, G.W.; Jeffrey, S.S. Liquid biopsy enters the clinic-Implementation issues and future challenges. Nat. Rev. Clin. Oncol. 2021, 18, 297-312. [CrossRef]

342. Clery, E.; Pisapia, P.; Vigliar, E.; Malapelle, U.; Bellevicine, C.; Troncone, G.; Schmitt, F.C. Role of Cytomorphology in the Era of Liquid Biopsy. Acta Cytol. 2019, 63, 497-505. [CrossRef]

343. Liu, H.E.; Vuppalapaty, M.; Wilkerson, C.; Renier, C.; Chiu, M.; Lemaire, C.; Che, J.; Matsumoto, M.; Carroll, J.; Crouse, S.; et al. Detection of EGFR Mutations in cfDNA and CTCs, and Comparison to Tumor Tissue in Non-Small-Cell-Lung-Cancer (NSCLC) Patients. Front. Oncol. 2020, 10, 572895. [CrossRef]

344. Leone, G.; Passiglia, F.; Bironzo, P.; Bertaglia, V.; Novello, S. Is there any place for immune-checkpoint inhibitors in the treatment algorithm of fusion-driven non-small cell lung cancer?-A literature review. Transl. Lung Cancer Res. 2020, 9, $2674-2685$. [CrossRef]

345. Mazieres, J.; Drilon, A.; Lusque, A.; Mhanna, L.; Cortot, A.; Mezquita, L.; Thai, A.; Mascaux, C.; Couraud, S.; Veillon, R.; et al. Immune checkpoint inhibitors for patients with advanced lung cancer and oncogenic driver alterations: Results from the IMMUNOTARGET registry. Ann. Oncol. 2019, 30, 1321-1328. [CrossRef] 